\title{
切羽前方地山予測を目的とした傾斜計測手法の 適用範囲と定量評価検討
}

\author{
坂井 一雄 1 - 谷 卓也 2 - 青木 智幸 $3 \cdot$ 岸田 潔 4 \\ 1正会員 大成建設株式会社 技術センター（干245-0051 神奈川県横浜市戸塚区名瀬町344-1） \\ E-mail: skikzo01@pub.taisei.co.jp (Corresponding Author) \\ 2正会員 大成建設株式会社 技術センター（†245-0051 神奈川県横浜市戸塚区名瀬町344-1） \\ E-mail: takuya.tani@sakura.taisei.co.jp \\ 3フェロー会員大成建設株式会社＼cjkstart技術センター（†245-0051 神奈川県横浜市戸塚区名瀬町344-1） \\ E-mail: aoki@sakura.taisei.co.jp \\ 4正会員 京都大学大学院教授 工学研究科（干615-8540 京都府京都市西京区京都大学桂C1-2） \\ E-mail: kishida.kiyoshi.3r@kyoto-u.ac.jp
}

\begin{abstract}
山岳トンネルの安全かつ経済的な施工には, 切羽前方の地山状況を精度よく予測して, 必要に応じて予 防保全的な対策工を講じる事が重要である。これまでに筆者らは，日常の施工管理の一環として，簡易に 実施できるトンネル天端部の傾斜計測によって, 切羽前方地山の硬軟変化を予測する手法を考案し, 数值 解析や現場計測試験で妥当性と有効性を確認してきた。本論文では, 提案手法によって切羽前方地山予測 を実現できる条件を明確化する目的で，土被りや地山剛性をパラメータとした感度解析を実施した。また， 傾斜計測による地山状況予測結果を, 変形余裕量の設定や補助工法の検討に対して実務的に活用すること を目指して，傾斜角度から天端沈下量を定量的に推定する方法を検討し，現場実装試験の事後評価で有効 性を確認した.
\end{abstract}

Key Words: inclination monitoring, prognosis of geotechnical condition ahead of tunnel face, crown settlement, numerical simulation, field measurement

\section{1. はじめに}

山岳トンネルは一般的に地下深部に構築される長距離 の線状構造物であるため，施工前に実施される地盤調査 によって必要な地山条件（地質学的情報や力学的・水理 学的条件）をすべて把握することは困難である. 一方， 山岳トンネル工法の安全性や経済性を含む施工方法の成 立性は切羽が自立するかどうかが前提条件となるため, 掘削前に地山条件をできるだけ正確に把握することが重 要である. このため, 施工時に切羽前方探查や切羽前方 地山予測を実施して, 事前地盤調査の不確実性を補完し 施工の安全性を確認寸ることが求められる. また，切羽 前方の地山状況の変化を知ることで，予防保全的に天端 安定や鏡面安定を目的とした対策工や，支保の仕様変更 や適切な変形余裕量を検討できるため, 重大な工期遅延 やコスト超過を引き起こす切羽崩落や修正掘削を未然に 防ぐことができる．したがって，事前に精度良く切羽前 方の地山状況を予測することは工期を遵守し経済的な卜
ンネル施工にも通ずる.

一般的に切羽前方探査は，先進ボーリングによるもの と坑内弾性波探査による手法に分類される. 先進ボーリ ングは，ドリルジャンボを用いたノンコアボーリングを 用いた削孔検層の適用事例が多数報告されている ${ }^{1) 4}$. これは，調査において別途ボーリングマシンを手配する ことなく，簡易かつ迅速な試錐作業が可能であるためで ある. 削孔検層は, 削孔時の打撃圧, 回転圧, フィード 圧，ダンピング圧といった削岩機の作動油圧と削孔距離 の関係を取得して，岩盤強度と相関関係にあると言われ る掘削体積比エネルギー5)のを算出するものである．比 較的簡便に実施でき, 切羽前方の数十メートル（最大 $50 \mathrm{~m}$ 程度 》) まで, エネルギ一值という定量的評価指標 によって地質状況を把握できる点が特徵である.ただし， ボーリング断面積は切羽断面積に比べて点のごとく小さ いため，必ずしもその情報が切羽前方地山の状況を代表 するとは言えない，また，掘削結果として生じる地山変 形量は, 削孔検層データから直接的には評価もしくは予 
測することはできない点が課題である.

坑内弾性波探査では，反射法弾性波探査を利用した TSP(Tunnel Seismic Prediction))が普及している. TSP に代表 される坑内弾性波探査は，切羽進行方向に延長の長いボ ーリング作業を伴わずとも，比較的切羽遠方までの探査 を実施することができるという点で利点があるものの， 切羽近傍で発破や打撃などの探査作業を要し，少なから ず掘削工程に影響を与えること，ならびに探査作業や探 査結果の分析に専門の技術者を必要とするため，相応の 探査費用が発生する点が課題である.

一方，切羽到達前から掘削に伴う地山挙動を計測し， できるだけ早い段階で，軟弱区間や断層破砕帯における 地山の不安定化，および周辺構造物への影響を把握しよ うとする切羽先行変位計測も実施される場合がある。こ のうち，既存インフラ施設や道路利用状況等の制約で地 表面の用地利用が困難で，トンネル坑内から計測器を設 置せざるを得ないような事例では，これまでに切羽先行 沈下計測 9)13) と切羽押出し変位計測 14), 15)が実施されてい る. 例えば，道路直下かつ既設インフラ施設が多数埋設 された直下の都市部山岳トンネル工法による地下駅建設 事例で，両者を組み合わせて切羽前方の予見していない 地山条件が，地表面や周辺構造物に与える影響や切羽の 安定性に及ぼす影響を切羽到達前から確認して，トンネ ル全線において網羅的に厳密な計測管理を試みた事例が

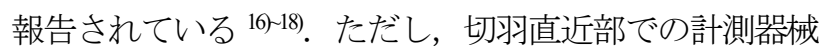
の設置作業や養生作業が，少なからず切羽作業の支障に なること，また専門の計測技術者を必要とするため，コ ストに与える影響が大きい. したがって，トンネル全線 に導入することは一般的に難しく，トンネル標準示方書 では特別な地山条件や周辺環境に応じて, 追加で実施さ れる計測項目（計測 B）に分類されている ${ }^{19)}$.

上述した一般に実施される切羽前方探査や切羽先行変 位計測のコストや工程に与える影響を抑制し，トンネル 全線で日常の計測管理の一環として実施できる切羽前方 地山評価手法として，坑内変位計測結果を活用する手法 が提案されている. 次章では, 同手法について概説し, 主に計測精度や計測間隔が課題となり適用範囲が限定的 であることを論じる. その上で，本研究の目的を示す.

\section{2 坑内変位計測による切羽前方地山予測}

\section{（1）予測手法の特徵と課題}

通常の坑内変位計測では，坑壁に設置した変位ターゲ ットの沈下や水平変位といった断面内の挙動に着目して, 地山の安定性と支保の安全性を評価する.この断面内変 位に加えて，切羽進行方向の変位（以下，トンネル軸方 向変位と称す）を評価することによって，切羽前方の地
山の硬軟変化を予測する手法が提案されている. Schubert and Budil ${ }^{20)}$ は，切羽前方で地山の剛性変化がある と，掘削に伴う応力再配分の影響で軟弱層が硬質層側に 引き付けられるように挙動することを明らかにした．例 えば，硬質層から軟弱層に向かって掘削する場合には， 切羽が軟弱層に近づくと，硬質層一様であるときに比べ て，軟弱層が坑内に押し出される挙動が大きくなる．こ の変形挙動の向きがトンネル軸方向と一致するため, ト ンネル軸方向変位は断面内変位に比べて，上記の挙動の 影響に鋭敏に反応する.そこで, Schubert and Budil ${ }^{20)}$ はト ンネル軸方向変位（L) と断面内変位 $(S)$ の比である $L / S$ 比によって, 切羽前方の地山の硬軟変化を予測でき ると提案した。 この手法の特徴は，切羽前方探査や切羽 先行変位計測のように, 煩雑な探査や計測器設置作業を 必要としないため，掘削作業に影響を与えず，工程への 影響が極めて小さいことである．また，トータルステー ションを用いた通常の変位計測結果の評価方法を工夫す るものであるため, 予測に際して追加計測コストが発生 せず，トンネル全線を通して予測を実現することも容易 である点も利点に挙げられる. 本手法は，オーストリア のトンネルプロジェクトで多数報告例があり，例えば,

Wolfsgruben トンネル 21), Spital トンネル22)，Koralm トンネ ル 23)での実施例がある。昨今では，同国の地盤工学会が 発行する計測ガイドラインで，坑内変位計測結果の活用 方法として標準的に実施する項目の一つに挙げられてい る ${ }^{24)}$.また， $L / S$ 比に限らず，トンネル軸方向変位を評 価して切羽前方の地山の硬軟変化を予測しようとする研 究は, 他には小泉ら ${ }^{25)}$, 寺島ら ${ }^{26)}$, 竹村ら ${ }^{27,28)}$,

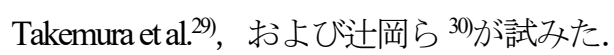

しかしながら，トンネル軸方向変位をトータルステー ションによる測量作業を用いて評価することの課題は青 木ら ${ }^{31)}$ ，および工藤ら ${ }^{32)}$ が指摘している.

トータルステーションの測角精度は，例えば SOKKIA

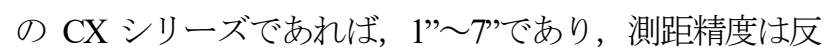
射シートを使う場合には，3 mm+2 ppm $\times X(\mathrm{ppm}: 1 / 100$ 万, $X(\mathrm{~mm})$ : 測定距離) で，プリズムを使う場合には， $2 \mathrm{~mm}+2 \mathrm{ppm} \times X$ である ${ }^{33)}$. 山岳トンネルの坑内変位計測 用では，2”３”の測角精度のトータルステーションが良 く使われおり，ターゲットは反射シートの使用例が多い. 坑内変位計測は, 計測断面の数十 $\mathrm{m}$ 後方から計測断面の トンネル壁面に設置された測量ターゲットを視準するた め, 坑内変位のうち断面内変位は測角精度に大きく依存 する. 一方，トンネル軸方向変位は視準方向とほぼ平行 な変位であるため，測距精度に大きく依存する．例えば， 測定距離が $50 \mathrm{~m}$ の場合を想定すると, 断面内変位は, $0.7 \mathrm{~mm}\left(50,000 \mathrm{~mm} \times \sin \left(3^{\prime \prime}\right)=0.7 \mathrm{~mm}\right)$ ，軸方向変位は 2.1 $\sim 3.1 \mathrm{~mm} \quad(2 \sim 3+2 / 1,000,000 \times 50,000=2.1 \sim 3.1 \mathrm{~mm})$ の計測誤 差を考慮する必要がある. 特にトンネル軸方向変位は計 


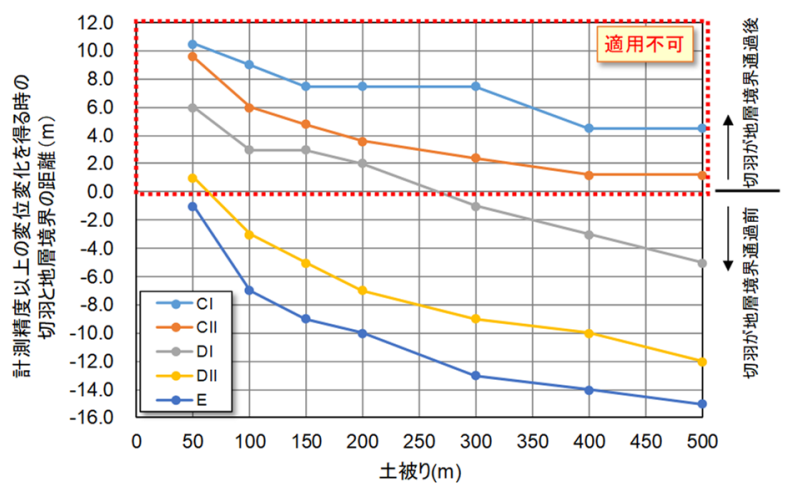

図-1 $L / S$ 比による切羽前方地山の予測可能距離 ${ }^{34)}$

測誤差が断面内変位に比べて大きいため，軸方向変位が 小さい場合には，坑内変位による地山予測結果は計測精 度の影響を受ける可能性があると考えられる。

坂井と岸田 ${ }^{34}$ は，種々の土被りと地山剛性の組み合わ せをパラメータとしたトンネル掘削の感度解析を実施し， トンネル軸方向変位と天端沈下が，切羽が地層境界に到 達する前に, 計測精度（トンネル軸方向変位 : $2 \mathrm{~mm}$, 天端沈下： $1 \mathrm{~mm}$ と仮定）以上に変化し，坑内変位計測 手法による予測が実現できる範囲を検証した．図-1は, 道路トンネルの地山等級毎に，土被りの大きさと計測精 度以上の变位変化を得る時の切羽と地層境界の距離（予 測可能距離）を示したものである. 図-1 の赤点線枠内

（緹軸が $0 \mathrm{~m}$ 以上）は，切羽が地層境界を通過した後で， 初めて計測精度以上の変位変化が得られる時の土被りと 掘削中の地山等級であり, 切羽前方地山予測が成立しな い範囲を示す，したがって，道路トンネルで使われる地 山等級で，CI および CII 地山の場合には土被り $500 \mathrm{~m}$ ま で, DI 地山の場合には土被り $300 \mathrm{~m}$ までの初期地圧条件 では，計測精度の課題が顕在化し，坑内変位計測による 予測手法は適用できない，すなわち，坑内変位計測によ る切羽前方地山予測手法は土被りが大きい，または岡性 が小さくて変形が生じやすいトンネル施工条件に適用可 能な範囲が限定されることがわかった.

一方，坑内変位計測の計測断面間隔は，小土被り区間 や地質の変化が激しい場合を除き一般的に 20〜30 m で

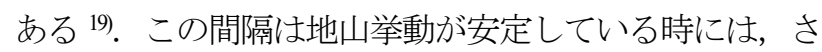
らに広げられる場合もある。しかし，L/S 比やトンネル 軸方向変位を用いて切羽前方の地山状況を見逃さずに捉 えようとする場合には，予測可能距離と計測断面間隔の 関係によっては, 計測断面間で予見しない地山変化に遭 遇する，例えば，図-1を参照すると，最も予測可能距離 が長い土被り $500 \mathrm{~m}$ の 地山であっても $15 \mathrm{~m}$ 前方までし か予測できないことを示唆している. 寸なわち，標準的 な計測間隔 $(20 \sim 30 \mathrm{~m})$ では計測断面間で地山変化点に 遭遇する可能性があり, 計測間隔の課題が明確にされた.

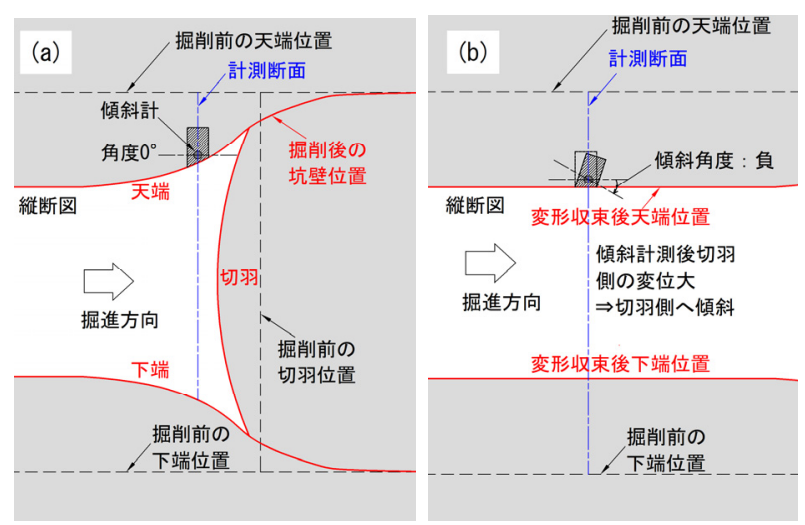

図-2 トンネル周辺地山の挙動と天端の傾斜角度 (a) 切羽近傍, (b) 切羽通過後の変形収束時

\section{(2) 本研究の目的}

これまでに坂井ら ${ }^{35}$ は，切羽前方地山評価を坑内変位 計測により実施する際に生じる問題点を解決するため, トンネル天端の切羽進行方向の傾斜角度変化を計測し, 切羽前方の地質の硬軟変化を予測する手法を提案した. 本論文では，土被りと地山剛性をパラメータとして感度 解析を実施し，傾斜計測による切羽前方地山予測手法の 適用可能範囲の明確化を図った。 また, 感度解析結果を 用いて地山変化を見逃すことのない適切な傾斜計測断面 間隔の設定方法を検討した。 さらに，切羽前方の地山予 測結果の実務的な活用方法の拡大を目的として，傾斜計 測結果から計測断面および切羽前方で発生しうる天端沈 下量の収束值を推定する手法を検討した.

\section{3. 坑内傾斜計測による切羽前方地山予測}

\section{(1) トンネル天端部の傾斜角度}

図-2(a)は切羽近傍の縦断図で，掘削に伴うトンネル周 辺地山の変形挙動を概念的に示したものである. 物性や 応力状態が進行方向に一様で，地山が弾性的な挙動を示 すと仮定すると，掘削に伴いトンネル壁面および切羽面 は内空側に押し出すように挙動する．掘削後に壁面に相 当する位置の地山は切羽到達前から徐々に内空側に向か って動き，切羽通過直後に大きく変形寸る. ここで，切 羽近傍の天端部において，トンネル進行方向の傾斜角度 を計測する事を想定する. 切羽通過直後の天端部に傾斜 計を設置して初期值を取得すると，それ以後の壁面形状 の変化増分が計測される. この時, 切羽が進行すると, 計測器を設置した断面よりも, さらに切羽側の方が変形 の増分が大きいために，図-2(b)のような切羽側に向かっ て倒れるような傾斜角度が発生する。これまでに，掘削 方式として機械掘削 35130および発破掘削 37を用いたトン ネル施工現場で複数回の計測を実施したが，計測断面よ 


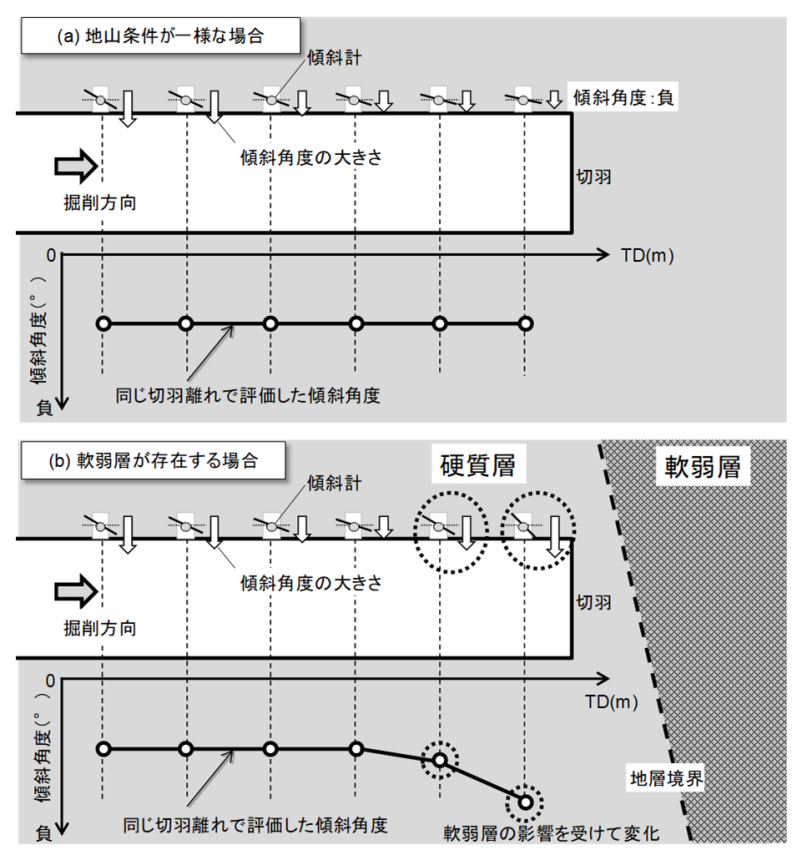

図-3 傾斜角度のトンネル距離程分布

(a)一様な地山条件, (b) 軟弱層が存在する場合

りも後方で下半部の掘削に伴う応力解放が起こる場合や, 地山剛性が高く天端沈下を生じない場合を除き，ほとん どのケースにおいて，切羽側に向かう傾斜角度が計測さ れている. また, 後述の現場実装試験結果でも同様の傾 向である.

\section{（2）地層境界手前での傾斜角度変化と定性的評価手法}

掘削対象となる地山性状が一様である場合，傾斜角度 の初期值取得時の，計測断面と切羽の距離（以後，切羽 離れと称す）を計測断面毎に一定にして，評価時の切羽 離れも同一とした時に，トンネル距離程（図-3の TD） で傾斜角度をプロットすると，図-3(a)のように一定の傾 斜角度分布となる。一方，切羽前方に，断層破砕帯の上 うな，現在掘削中の地山条件と比較して地山剛性の劣る 軟弱層が存在する場合には，剛性コントラストの影響を 受けて，掘削に伴う応力再配分により，地層境界手前の 硬質層側に応力集中を生じる。逆に軟弱層側から硬質層 側に向かって掘削を行った場合には，地層境界前方の硬 質層側に応力集中が生じる，先述のように，地層境界近 傍の地山挙動変化は Schubert and Budil20)によって示され, 現場計測 21-23)や数值解析 ${ }^{38} 4$-40)によって検証した例がこれ までに報告されている.

坂井ら ${ }^{35)}$ と Sakai et al. ${ }^{30}$ は，地山の硬軟変化がある場合 には，坑内変位と同様にトンネル天端の傾斜角度も，図 -3(b)に概念的に示すように地層境界手前で変化があるこ とを弾性三次元逐次掘削解析によって明らかにした. ま た，土被りが $200 \mathrm{~m}$ で硬質層の変形係数が $D=1000 \mathrm{MPa}$,

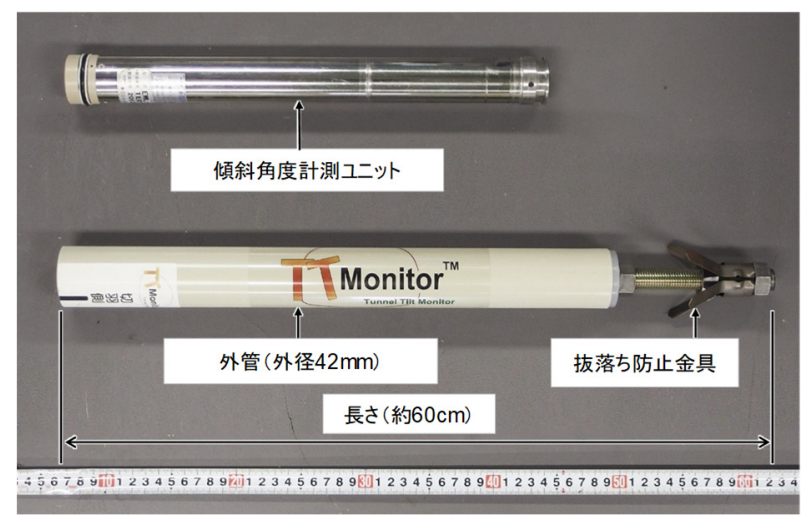

写真-1 天端傾斜計

軟弱層の変形係数が $D=100 \mathrm{MPa}$ という地山剛性コント ラストの場合, 傾斜角度の変化量が開発した天端傾斜計 （写真-1）の計測精度 $0.01^{\circ}$ (読取分解能 $0.001^{\circ}$ ) に対し て十分大きくなることを示した. この検討結果から, 卜 ンネル進行方向に一定の間隔で傾斜計測を実施し, 傾斜 角度の標準的な值（以後, 傾斜角度標準值と称す）を把 握した後, その傾斜角度標準值からの相対的な変動量に 着目して, 式(1)で切羽前方地山の硬軟変化を定性的に 評価する手法を考案した.

$$
\begin{array}{llll}
D_{\text {forward }}>D_{n} & \text { if } & & \Delta \phi>0 \\
D_{\text {forward }}=D_{n} & \text { if } & & \Delta \phi=0 \\
D_{\text {forward }}<D_{n} & \text { if } & & \Delta \phi<0
\end{array}
$$

ここで， $D_{\text {forward }}$ は切羽前方地山の変形係数， $D_{n}$ は傾斜 角度算出断面での地山の変形係数, $\Delta \phi$ は計測された傾 斜角度標淮值からの変動量である.

提案手法の有効性と天端傾斜計の適用性は複数の現場 実装試験によって確認された 35,377,411. しかし，地層境界 近傍での傾斜角度標準值からの変動量は, 土被りに伴う 初期地圧の大きさや切羽が存在する箇所の地山岡性と切 羽前方の地山岡性のコントラストよって変化する. そこ で, 次章ではこれらをパラメータとした感度解析を実施 して提案手法の適用可能範囲について検討した.

\section{4. 傾斜計測手法の適用可能範囲}

\section{(1) 解析条件}

感度解析は掘削半径 $r=5 \mathrm{~m}$ の円形トンネルで実施し た. トンネルの土被りは $50 \mathrm{~m}, 100 \mathrm{~m}, 150 \mathrm{~m}, 200 \mathrm{~m}$, $300 \mathrm{~m}, 400 \mathrm{~m}$, および $500 \mathrm{~m}$ を検討した. 初期地圧条件 は，鉛直方向応力は深度相当の土被り圧とした. 水平方 向応力は, 鉛直方向応力との比である側圧係数 $K$ を道路

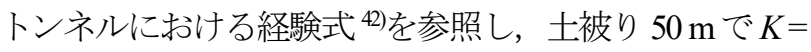


表-1 解析用地山物性值と 1 掘進長

\begin{tabular}{|c|r|r|r|}
\hline 地山等級 & $\begin{array}{c}\text { 変形係数 } \\
D(\mathrm{MPa})\end{array}$ & $\begin{array}{c}\text { ポアソン比 } \\
(-)\end{array}$ & $\begin{array}{c}\text { 1掘削長 } \\
I_{r}(\mathrm{~m})^{*}\end{array}$ \\
\hline $\mathrm{Cl}$ & 2,000 & 0.30 & 1.5 \\
\hline $\mathrm{Cll}$ & 1,000 & 0.30 & 1.2 \\
\hline $\mathrm{DI}$ & 500 & 0.35 & 1.0 \\
\hline $\mathrm{DII}$ & 150 & 0.40 & 1.0 \\
\hline $\mathrm{E}$ & 80 & 0.40 & 1.0 \\
\hline
\end{tabular}

*領域Iでの掘削長を領域Iも継続する

表-2 地山条件の組み合わせ

\begin{tabular}{|c|c|c|c|c|c|c|}
\hline \multirow{2}{*}{\multicolumn{2}{|c|}{$\begin{array}{l}\text { 地山等級の } \\
\text { 組み合わせ }\end{array}$}} & \multicolumn{5}{|c|}{ 領域川の地山等級 } \\
\hline & & $\mathrm{Cl}$ & $\mathrm{Cll}$ & DI & DII & E \\
\hline \multirow{5}{*}{$\begin{array}{c}\text { 領域|の } \\
\text { 地山等級 }\end{array}$} & $\mathrm{Cl}$ & - & $\mathrm{Cl} \rightarrow \mathrm{CII}$ & $\mathrm{Cl} \rightarrow \mathrm{Dl}$ & $\mathrm{Cl} \rightarrow \mathrm{D} \|$ & $\mathrm{Cl} \rightarrow \mathrm{E}$ \\
\hline & $\mathrm{Cll}$ & $\mathrm{Cl} \rightarrow \mathrm{Cl}$ & - & $\mathrm{Cll} \rightarrow \mathrm{DI}$ & $\mathrm{C} \| \rightarrow \mathrm{D \|}$ & $\mathrm{C} \| \rightarrow \mathrm{E}$ \\
\hline & $\mathrm{DI}$ & $\mathrm{DI} \rightarrow \mathrm{Cl}$ & $\mathrm{DI} \rightarrow \mathrm{CI}$ & - & $\mathrm{Dl} \rightarrow \mathrm{DI}$ & $\mathrm{Dl} \rightarrow \mathrm{E}$ \\
\hline & DII & $\mathrm{D} \| \rightarrow \mathrm{Cl}$ & $\mathrm{D \|} \rightarrow \mathrm{C} \|$ & $\mathrm{D \|} \rightarrow \mathrm{DI}$ & - & $\mathrm{D \|} \rightarrow \mathrm{E}$ \\
\hline & $E$ & $\mathrm{E} \rightarrow \mathrm{Cl}$ & $\mathrm{E} \rightarrow \mathrm{Cll}$ & $\mathrm{E} \rightarrow \mathrm{DI}$ & $\mathrm{E} \rightarrow \mathrm{D} \|$ & - \\
\hline
\end{tabular}

0.75 とし，土被り $100 \mathrm{~m}$ 以上のケースでは $K=1.0$ とした.

地山の応力ーひずみ関係は線形弾性とした。地山条 件の組み合わせは，道路トンネルの地山等級を想定し， 各地山等級の代表物性值 ${ }^{43}$ 力らら変形係数とポアソン比を 使用した．ただし，地山等級 B は判定される事例が少な いため除外し，参考文献 44に示される地山等級 $\mathrm{E}$ の代表 物性值（変形係数 $D=80 \mathrm{MPa}$ ）を追加して検討した.

解析上は支保をモデル化せず，掘削に伴う地山挙動 のみを検討対象とした。 これは地山等級毎の標淮的な支 保パターン ${ }^{45}$ の適用で，トンネル周辺地山が崩落等を生 じず連続体的な挙動をする事だけを期待したものである. 掘削は各地山等級の標準支保パターンで示される 1 掘削 進行長 $\left(l_{r}\right)$ とし, 具体的には CI 地山で $l_{r}=1.5 \mathrm{~m}, \mathrm{CI}$ 地 山で $l_{r}=1.2 \mathrm{~m}, \mathrm{DI}, \mathrm{DII}, \mathrm{E}$ 地山では $l_{r}=1.0 \mathrm{~m}$ を採用した.

表-1 に解析で用いた地山等級毎の地山物性值と 1 掘削進 行長を示寸．表-2の地山条件の組み合わせのように，土 被り 1 ケースあたり，20通りの地山条件の組み合わせが あるため，合計 140 ケースの感度解析を実施した。

図-4に三次元解析メッシュを示す．トンネル掘進方向 の中央位置に地質境界を設け，その前後に異質な変形特 性を持つ地山があることを想定した．また，トンネル横 断方向には地質が変化しないと仮定し，半断面モデルの 解析を実施した．解析モデルの境界条件は変位固定境界 とし，トンネル壁面から上下および側方境界までの距離 は $50 \mathrm{~m}(=10 r)$ とした. トンネル軸方向のモデル延長 は地層境界より手前側（領域 I）での 1 掘削長 $l$ r基準と して，地層境界前後に $120 l_{r}$ の延長を設け，領域 $\mathrm{I}$ の地山 条件毎に設定した 1 掘削長をモデル化できるようにした.

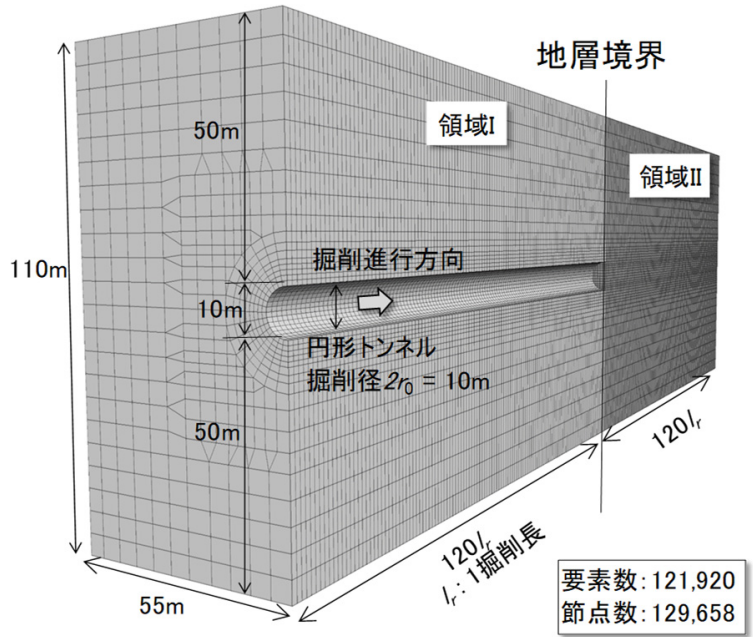

図-4 三次元解析メッシュ

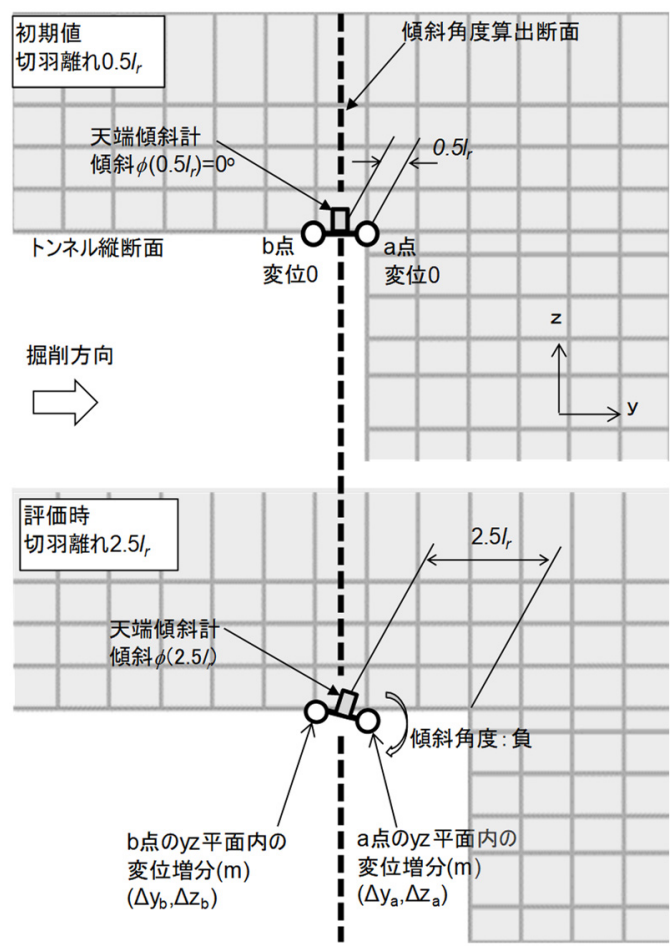

図-5 傾斜角度の算出方法

\section{(2) 解析結果}

トンネル天端位置の節点変位から傾斜角度を算出した。 傾斜角度の算出方法を図-5を用いて説明する. 天端傾斜 計は切羽が計測断面を通過後すぐに設置できるため，初 期值（傾斜角度 $0^{\circ}$ ） は切羽離れ 0.5 l r で取得するものとし た. 傾斜角度の評価は経験的に初期值取得後に 2 回もし くは 3 回掘進した時点（切羽離れ $2.5 r$ もしくは $3.5 l_{r}$ ）で 実施している．乙の時点における傾斜角度算出断面前後 の天端部の 2 節点に着目し, 初期值取得時からの変位増 分の差を逆正接関数として傾斜角度を表現した。例えば, 図-5で切羽離れ $2.5 l_{r}$ の傾斜角度は式(2)のように表せる. 


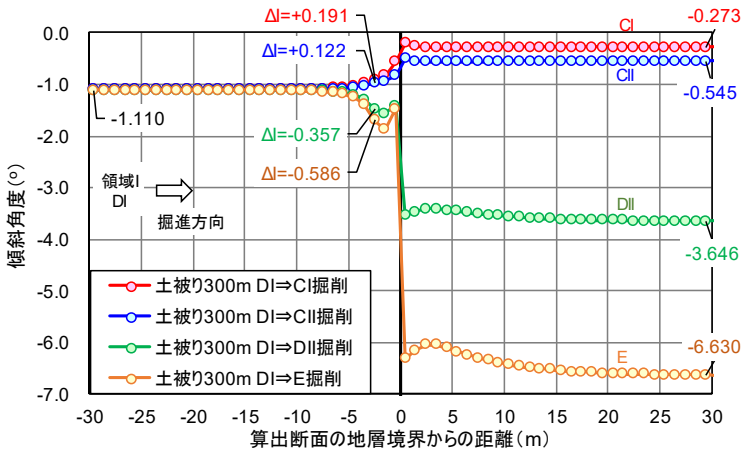

図-6 傾斜角度分布（土被り $300 \mathrm{~m}$ ，領域 I が DI 地山）

$$
\phi\left(2.5 l_{r}\right)=\frac{180}{\pi} \cdot \tan ^{-1}\left(\frac{\left(\Delta z_{a}-\Delta z_{b}\right)}{l_{r}+\left(\Delta y_{a}-\Delta y_{b}\right)}\right)
$$

ここで，傾斜算出断面より前方の節点（図-5の a 点）に おける初期值からのトンネル軸方向変位増分と鉛直方向 変位増分がそれぞれ $\Delta y_{a}, \Delta z_{a}$ である. 傾斜算出断面より 後方の節点（図-5 の b 点）の変位増分が $\Delta y b 、 \Delta z$ である. また，切羽側に傾斜する向きを負と定義した.

図-6に解析結果の例として，土被り $300 \mathrm{~m}$ において DI 地山の前方に異なる地山等級の領域が存在する時の傾斜 角度分布を示寸．傾斜角度は切羽離れ $2.5 l_{r}$ の值である.

地層境界から十分に離れた傾斜算出位置では，領域II の影響を受けず，傾斜角度はほぼ一定の值となる。この 值を傾斜角度標準值と称し，地層境界から約 $30 \mathrm{~m}$ 手前の 位置で算出した．土被り $300 \mathrm{~m} の \mathrm{DI}$ 地山では，傾斜角度 標準值は-1.110 と計算された。図-6では，切羽が地層境 界に到達した時の傾斜角度（すなわち，地層境界と傾斜 算出位置の距離が傾斜角度の評価タイミングの $2.5 l$ と等 しい時の傾斜角度）之傾斜角度標準值の差を示した（図 -6の $\Delta I)$ ．地層境界よりも前方がCI地山の場合 $\Delta I=+$ $0.191^{\circ}, C I I$ 地山の場合 $\Delta I=+0.122^{\circ}$, DII地山の場合 $\Delta I=$. $0.357^{\circ}$, E地山の場合 $\Delta I=-0.586^{\circ}$ である. 他の土被りと地 山条件でも同様に傾斜角度分布と傾斜角度標準值からの 変動量に対して計測精度を考慮して考察した.

\section{(3) 予測可能距離に関する考察}

天端傾斜計の計測精度は $0.01^{\circ}$ であるため, 切羽が地 層境界手前にある時，切羽前方の地山变化に伴う傾斜角 度標準值からの変動量が，少なくとも $0.01^{\circ}$ 以上である ことが切羽前方地山予測の成立条件となる。 そこで, 各々の土被り, 地山条件での傾斜角度標準值から $0.01^{\circ}$ 以上の変化が得られる時の切羽と地層境界の距離を算出 した．このうち，表-3に土被りが $300 \mathrm{~m}$ の時の算出結果 を示寸，図-7 は傾斜角度評価時の算出断面，切羽，およ び地層境界の位置関係の説明図である。

表-3 中の赤字（領域 Iが CI で領域 II が CII の場合）は 地層境界に到達以降でしか精度を考慮して有意な変化が
表-3 計測精度以上の傾斜角度を得る時の地層境界と切羽 の距離（土被り $300 \mathrm{~m}$ )

正: 地層境界通過後, 負: 地層境界通過前, 単位m

\begin{tabular}{|c|c|c|c|c|c|c|}
\hline \multirow{2}{*}{\multicolumn{2}{|c|}{ 土被り300m }} & \multicolumn{5}{|c|}{ 領域川の地山等級 } \\
\hline & & $\mathrm{Cl}$ & Cll & DI & DII & $E$ \\
\hline \multirow{5}{*}{$\begin{array}{l}\text { 領域|の } \\
\text { 地山等級 }\end{array}$} & $\mathrm{Cl}$ & & $\begin{array}{c}0.0 \\
(-3.75)\end{array}$ & $\begin{array}{c}-1.5 \\
(-5.25)\end{array}$ & $\begin{array}{c}-3.0 \\
(-6.75)\end{array}$ & $\begin{array}{c}-3.0 \\
(-6.75)\end{array}$ \\
\hline & Cll & $\begin{array}{c}-2.4 \\
(-5.40)\end{array}$ & & $\begin{array}{c}-2.4 \\
(-5.40)\end{array}$ & $\begin{array}{c}-4.8 \\
(-7.80)\end{array}$ & $\begin{array}{c}-6.0 \\
(-9.00)\end{array}$ \\
\hline & $\mathrm{DI}$ & $\begin{array}{c}-7.0 \\
(-9.50) \\
\end{array}$ & $\begin{array}{c}-5.0 \\
(-7.50) \\
\end{array}$ & & $\begin{array}{c}-7.0 \\
(-9.50)\end{array}$ & $\begin{array}{c}-8.0 \\
(-10.50) \\
\end{array}$ \\
\hline & DII & $\begin{array}{c}-16.0 \\
(-18.50)\end{array}$ & $\begin{array}{c}-15.0 \\
(-17.50)\end{array}$ & $\begin{array}{c}-14.0 \\
(-16.50)\end{array}$ & & $\begin{array}{c}-8.0 \\
(-10.50)\end{array}$ \\
\hline & $\mathrm{E}$ & $\begin{array}{c}-20.0 \\
(-22.50)\end{array}$ & $\begin{array}{c}-20.0 \\
(-22.50)\end{array}$ & $\begin{array}{c}-19.0 \\
(-21.50) \\
\end{array}$ & $\begin{array}{c}-16.0 \\
(-18.50) \\
\end{array}$ & \\
\hline
\end{tabular}

*上段: $0.01^{\circ}$ 以上の傾斜角度変化があるときの切羽と地層境界の距離

*下段: $0.01^{\circ}$ 以上の傾斜角度変化が得られる断面 (切羽位置 $-2.5 / r$ )

*赤字: 地層境界通過後に $0.01^{\circ}$ 以上の傾斜角度変化が得られるケース

*青枠: 領域 $\mid の$ 地山等級毎に最も切羽が地層境界に近づいて $0.01^{\circ}$ 以上の傾斜角度 変化が得られるケース

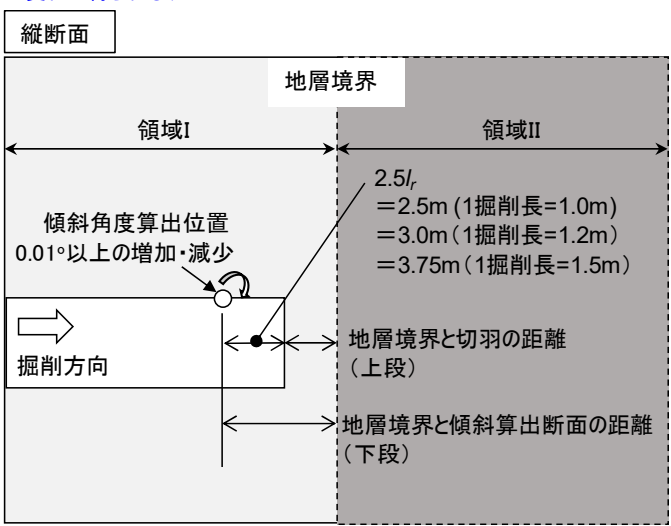

図-7＼cjkstart傾斜角度評価時の地層境界と切羽位置の関係

得られず，地山予測が成立しない地山条件の組み合わせ を表す．すなわち，土被り $300 \mathrm{~m}$ では CI 地山掘削中に CII 地山が前方に存在しても，傾斜角度は切羽が地層境 界に到達するまでには， $0.01^{\circ}$ 以上の変化は示さないこと を表す。一方，領域IがCII以下の地山条件の場合には， 領域 II 地山条件が解析で設定したどの等級の地山が存 在しても，切羽が地層境界に到達するまでに少なくとも $0.01^{\circ}$ は変化するため, 切羽前方の地山岡性が変化するこ とを予測することができる．青枠は，領域 I の地山条件 毎に，切羽が最も地層境界に近づいて，もしくは地層境 界を領域 II 側に通過した後最も遠くで，0.01以上の傾斜 角度変化が現れる地山条件の組み合わせをハイライトし たものである. この時の切羽と地層境界の距離が，領域 II の地山剛性に寄らず，地山変化を見逃さないという意 味で予測可能距離と表現する.

他の土被り条件でも同様の検討を行い，図-8のように 土被りと掘削中の地山条件（領域 I）に応じた傾斜計測 手法の予測可能距離を算出した．図-8のうち，縦軸の正 の範囲は，切羽が地層境界に到達して以降初めて傾斜角 度標準值から計測精度以上変化することを意味し，予測 手法が成立しない範囲である。この感度解析結果より, 傾斜計測手法の適用可能範囲は掘削中の地山条件に応じ 


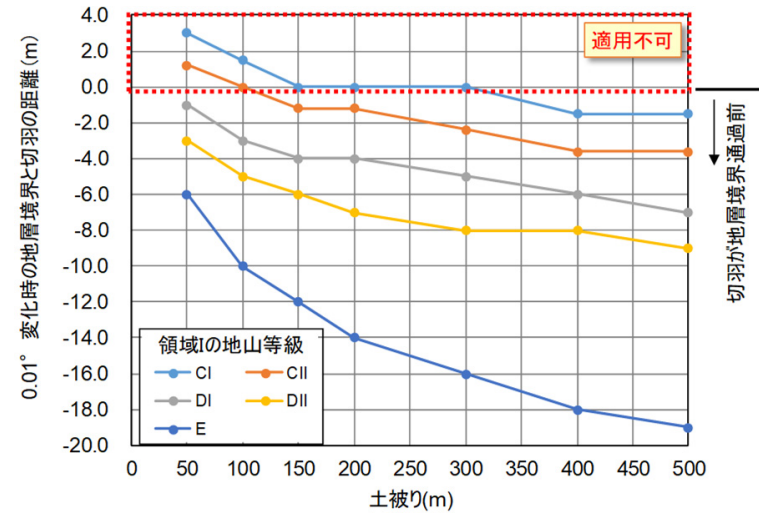

図-8 傾斜計測手法の適用可能範囲と予測可能距離

て，以下のように結論付けることができる.

・CI地山の場合には，土被り $400 \mathrm{~m}$ 以上で傾斜計測手法 は適用可能である.

• CII 地山の場合, 土被り $150 \mathrm{~m}$ 以上で適用可能である.

- DI 地山以下の剛性の場合, 土被り $50 \mathrm{~m}$ 以上で適用可 能である.

この適用可能範囲は，図-1 で示した坑内変位計測手法 の適用可能範囲 ${ }^{34}$ を検討した際と同じ解析条件で実施し た. 図-1 と比較すると傾斜計測手法の方が適用可能範囲 が広く, 予測感度の面で優位性があると言える.

また，図-8 は適切な計測間隔を設定するノモグラム （計算図表）としても使用することができる，例えば， 土被り $300 \mathrm{~m}$ でDI地山を掘削している場合には，予測可 能距離が $5 \mathrm{~m}$ である.このため, $5 \mathrm{~m}$ 以下の計測間隔を 設定することで，掘削中の地山と比較して硬軟どちら に変化する場合も，地山変化を見逃す事は無い。この

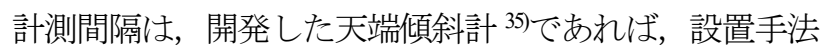
が簡便でかつ自動計測が可能であるため，施工に影響 を与える事なく実施可能である.

ここで，図-8は地山の応力ーひずみ関係を線形弾性と し, 掘削半径 $r=5 \mathrm{~m}$ の円形トンネルで, 全断面掘削工 法を採用した時の数值計算結果である. 掘削に伴う応力 再配分の影響で, トンネル周辺に地山強度を超える応力 が発生し塑性域が生じる場合には，厳密には弾塑性解析 により予測可能距離と予測が成立する計測間隔の検討を 行う必要がある. ただし，地山の応力一ひずみ関係を弾 塑性とした場合には，線形弾性条件よりも大きなトンネ ル壁面変位が発生するため, 式(2)で計算される傾斜角 度の絶対值も増加する。このため, 計測精度を閾值とす る予測可能距離は弾塑性条件の方が長くなる傾向にあり, 少なくとも本検討で実施した弾性計算に基づく傾斜計測 手法の適用可能範囲や計測間隔は満足すると考えられる。 一方で, 土被りや掘削半径が異なる場合には, 数值計 算結果に対し次章で示寸補正が必要である.

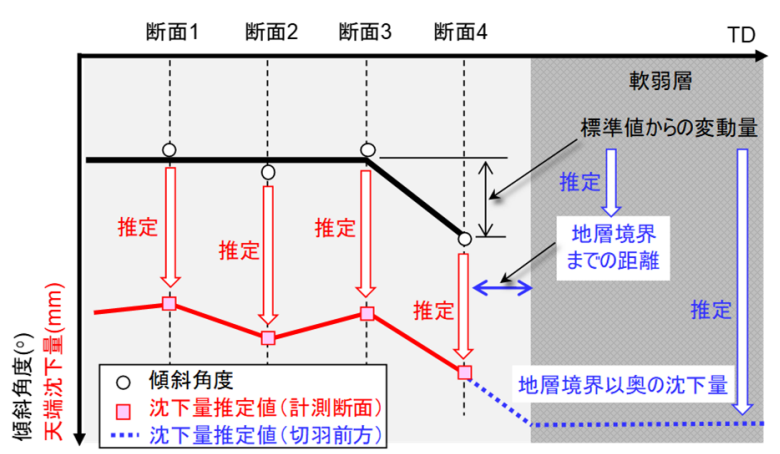

図-9天端沈下量推定方法の概念図

\section{5. 天端沈下量予測手法への発展}

本章では，地山予測結果を変形余裕量の設定等の実務 的な検討事項に活用寸ることを目的に，傾斜角度の值や 地山変化の予測結果から天端沈下量を推定する方法を検 討する．提案する天端沈下量予測手法は，図-9で概念的 に示すように，傾斜角度絶対值に着目した傾斜計測断面 における天端沈下量の早期推定方法 (図-9 中の赤字) ${ }^{40}$ と, 地層境界近傍での傾斜角度標淮值からの相対的変化 量に着目した切羽前方の天端沈下量推定方法（図-9中の 青字）に分類される.

\section{(1) 傾斜計測断面の天端沈下量推定方法 a) 傾斜角度と天端沈下量の相関性}

天端沈下量推定方法を検討するにあたり，まずその実 現可能性を検証するために，これまでに現場実装試験を 実施した椿坂トンネル 37) と箕面トンネル41)で得られた傾 斜角度（初期值取得後 2 掘削時点）と天端沈下量（切羽

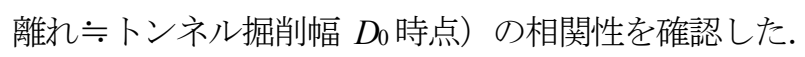
両トンネルは，道路トンネルで頁岩を主体とする岩盤に おいて, 計測区間では補助ベンチ付き全断面掘削工法が 採用された. 椿坂トンネルの掘削幅 $D_{0}$ は約 $10 \mathrm{~m}$, 箕面 トンネルの掘削幅 Doは約 $11 \mathrm{~m}$ である．両トンネル共に, 天端沈下量の収束值は最大でも $20 \mathrm{~mm}$ 程度であり, 後出 の葉山島トンネルと比較すると, 傾斜計測区間では大き な地山変化に遭遇しなかった事例である. 図-10 に椿坂 トンネルでの結果，図-11 に箕面トンネルの結果を示す。 傾斜角度の初期值は，椿坂トンネルでは切羽離れ $1.5 l r$ (CIIパターン $: l_{r}=1.2 \mathrm{~m}, \mathrm{DI}$ パターン $\left.: l_{r}=1.0 \mathrm{~m}\right)$ 時点, 箕面トンネルでは $0.5 l_{r} \quad\left(l_{r}=1.0 \mathrm{~m}\right)$ 時点である. 両図で は, ばらつきはあるものの, 天端沈下量と傾斜角度はあ る一定の比例関倸にあることが確認できる。 そのため, 傾斜計測結果は切羽前方地山の剛性変化を定性的に予測 するだけでなく，地山変化が見られない場合でも計測断 面位置の天端沈下量を推定することが可能であると考察 した. 傾斜計測は坑内変位計測に比べて, 計測断面間隔 


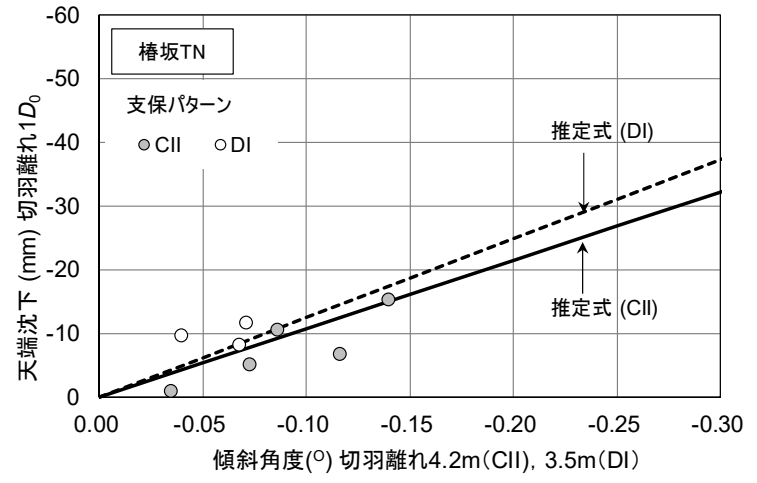

図-10 傾斜角度と天端沈下量の関係（椿坂トンネル）

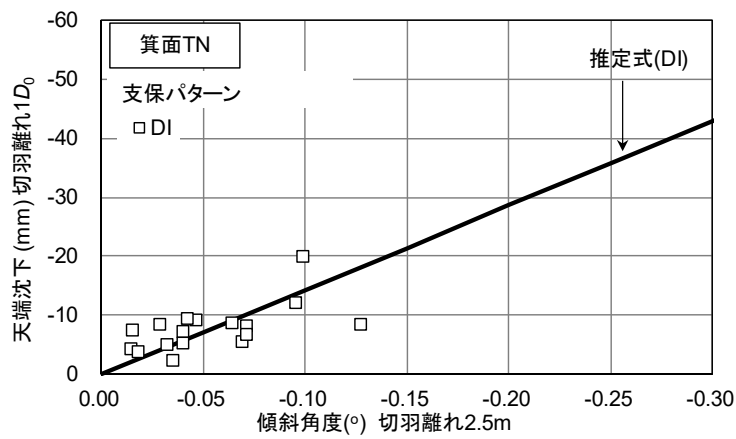

図-11 傾斜角度と天端沈下量の関係（箕面トンネル）

を簡単に密にすることができる事から，天端沈下の早期 推定方法の採用により，通常の変位計測断面の補間方法 に展開できると考えられる，そこで，次項のように推定 式を検討した。なお，図-10および図-11の実線および点 線は次項の推定式による傾斜角度と天端沈下量の関係を 示したものである.

\section{b) 天端沈下量推定式（傾斜計測断面）}

天端部の傾斜角度は既出の式(2)のように表した. 1 掘 削長 $l_{r}$ は一般に $1 \mathrm{~m}$ 以上で，トンネル軸方向変位の絶対 值よりも十分に大きく $l_{r} \gg\left(\Delta y_{a}-\Delta y_{b}\right)$ とみなすこと ができる。したがって，式(2)は式(3)のように近似する 事ができる.

$$
\phi\left(2.5 l_{r}\right)=\frac{180}{\pi} \cdot \tan ^{-1}\left(\left(\Delta z_{a}-\Delta z_{b}\right) / l_{r}\right)
$$

傾斜角度の初期值（切羽離孔 $0.5 r$ ）取得時からの天端沈 下量の増分である $z_{a}$ および $\Delta z b$ を切羽離れに応じた天端 沈下量で表現すると式(4)のように表せる.

$$
\begin{array}{r}
\phi\left(2.5 l_{r}\right)=\frac{180}{\pi} \cdot \tan ^{-1}\left\langle\left[\left\{z\left(2 l_{r}\right)-z(0)\right\}\right.\right. \\
\left.\left.-\left\{z\left(3 l_{r}\right)-z\left(l_{r}\right)\right\}\right] / l_{r}\right\rangle
\end{array}
$$

式(4)は，傾斜角度を切羽離れに応じた天端沈下量の関 数で表せることを意味する．そこで，天端沈下量の大き
さを変位特性曲線の近似式で推定する. Panet ${ }^{477}$ は弾性地 山中の円形トンネルの掘削解析で得られた，トンネル壁 面変位の経距変化をフィッティングする関数として式 (5)を提案した。なお，式(5)では壁面変位量を天端沈下 量 $z(y)$ として表現した.

$$
z(y)=z_{\infty}\left\{1-\exp \left(-y / 0.7 r_{0}\right)\right\}
$$

ここで，yは切羽離れ $(\mathrm{m}), z_{\infty}$ は切羽到達時を 0 とする天 端沈下量の収束值(m)，r 0 はトンネル掘削半径(m)を表す。 式(5)を式(4)へ代入すれば， $z_{\infty}$ は式(6)のように表せる。

$$
\begin{aligned}
& z_{\infty}=\tan \left\{\phi\left(2.5 l_{r}\right) \cdot \pi / 180\right\} \\
& \quad /\left[\left\{\begin{array}{c}
-\exp \left(-2 l_{r} / 0.7 r_{0}\right)+\exp \left(0 / 0.7 r_{0}\right) \\
+\exp \left(-3 l_{r} / 0.7 r_{0}\right)-\exp \left(-l_{r} / 0.7 r_{0}\right)
\end{array}\right\} / l_{r}\right]
\end{aligned}
$$

式(6)を用いることにより，切羽離れ $2.5 l$ rで評価した傾斜 角度の值から傾斜計測断面における天端沈下量の収束值 を推定できる．なお， $z_{\infty}$ を計測変位相当の沈下量とす るためには，初期值を取得した切羽離孔 $y$ における沈下 量を $z_{\infty}$ から控除する必要がある。例えば，初期值取得 時の切羽離れが $y=0.5 l$ r゙ある場合には, 計測変位相当 の天端沈下量収束值 $z_{\infty}^{\prime}$ は式(7)で表される.

$$
z_{\infty}^{\prime}=z_{\infty}-z\left(0.5 l_{r}\right)
$$

\section{c）推定方法の適用性検証}

式(6)の推定式の適用性を検証するため，現場実装試 験を行った椿坂トンネル ${ }^{37}$ および箕面トンネル ${ }^{41} の$ の傾斜 計測結果から天端沈下量を推定し，実測結果との比較を 行った.

図-12 に椿坂トンネルでの事後評価結果を示す．傾斜 角度による天端沈下量の推定では，掘削断面積と等価な 断面積を有する円形トンネルの掘削半径 $r$ を用いるもの とし，CII 支保パターン区間（掘削断面積 $54.6 \mathrm{~m}^{2}$ ) では $r 0=4.169 \mathrm{~m}$ ，DI 支保パターン区間（掘削断面積 $64.7 \mathrm{~m}^{2}$ ） では $n=4.538 \mathrm{~m}$ とした. ここで，掘削半径の違いは，CII および DI 支保パターンにおける支保量の違いとインバ 一ト設置の有無に起因寸る. 1 掘削長は CII 支保パター ン区間では $l_{r}=1.2 \mathrm{~m}, \mathrm{DI}$ 支保パターン区間では $l_{r}=1.0 \mathrm{~m}$ である。

傾斜角度計測断面と天端沈下計測断面が近接している 箇所では，計測区間全体にわたって整合的な結果が得ら れていると考えられる。傾斜角度を計測した TD1448 m および TD1461 m では，直近に天端沈下計測断面を設け なかったため，詳細な予測精度検証は難しいが，前後の 天端沈下量の值と推移傾向から考えて妥当な範囲で推定 


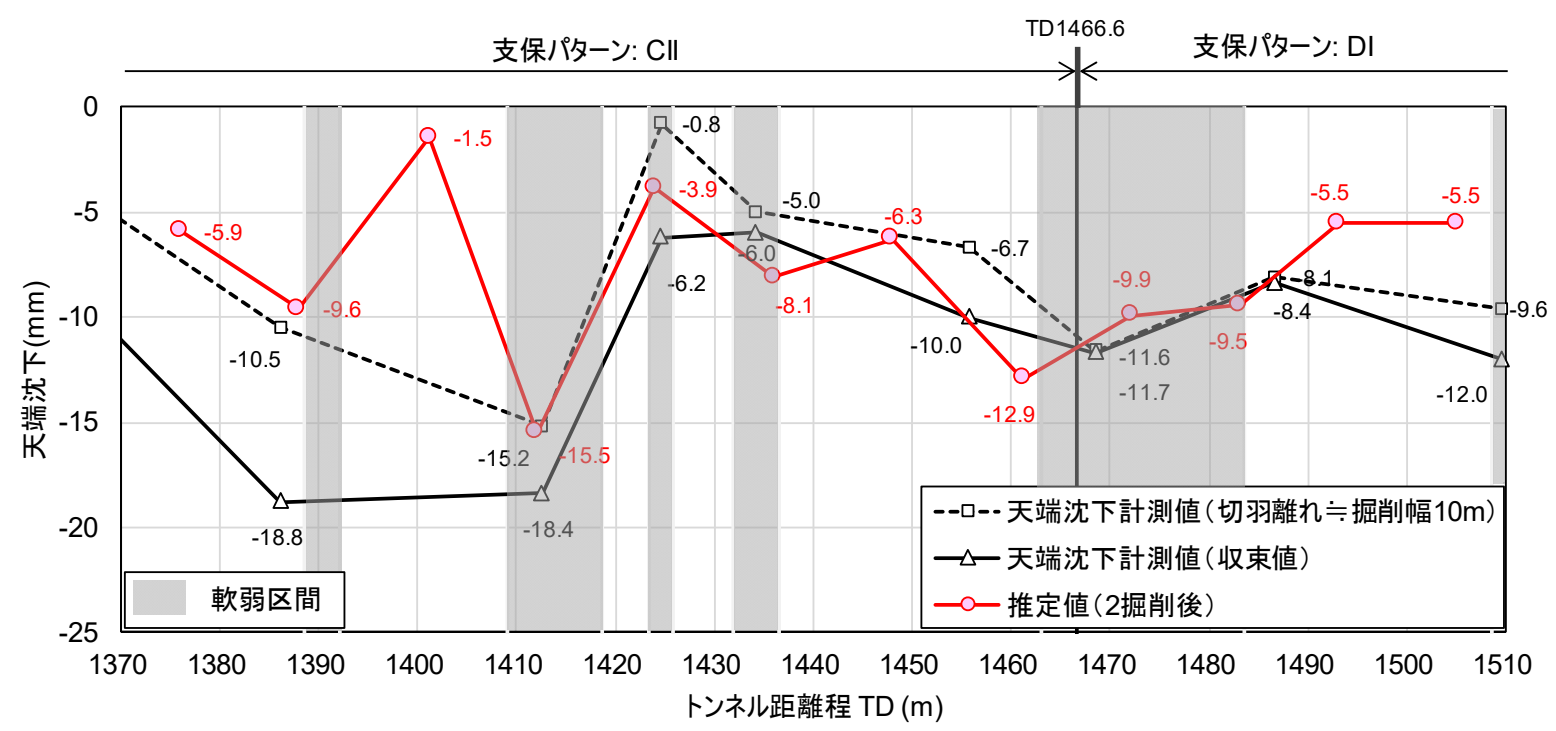

図-12 椿坂トンネルにおける天端沈下量推定方法の事後評価結果

できていると考えられる．TD1401.2 m，TD1493.1 m，お よびTD1505.1 mでは，直近の天端沈下計測結果に比べて， 小さな推定結果となったが，これらの計測断面は切羽観 察の結果では比較的硬質な地山条件であったことと定性 的には整合する.

TD1388 m では, 計測結果の収束値は-18.8 mmに対して, 推定值は-9.6 mm であり過小評価となった. この原因は 次のように考えられる．推定式に用いた変位特性曲線の フィッティング関数は弾性地山の挙動を仮定しているた め, 式(5)では切羽離れ 20 （=トンネル掘削幅）までに収 束沈下量の $94 \%$ 以上が発生する. 一方, TD1388 m の地 山挙動では, 図-12 より切羽離れ $10 \mathrm{~m}$ (ラトンネル掘削 幅）までに発生した沈下量は $56 \% （ 10.5 / 18.8=0.56 ） に$ 留まり, 切羽離れ $10 \mathrm{~m}$ 以降に大きな沈下を計測した事 が特徵的である. すなわち, 図-13 に示すように計測結 果と推定結果で変位特性曲線が大きく異なることが原因 である. 詳述すると, 傾斜角度による推定方法では, 切 羽離れ $4.8 \mathrm{~m}$ までに実際には収束時変形量の $30 \%$ しか発 生していない段階での傾斜角度をフィッティング関数に よって, 収束時の $71 \%$ まで沈下量が発生したように考え て, 収束沈下量を推定した. このため, 害際の計測結果 と比べて，過小な推定結果となったと考えられる.

次に，箕面トンネルでの事後評価結果を図-14 に示寸. 箕面トンネル（DI パターンの掘削断面積 $87 \mathrm{~m}^{2}$ ） での掘 削半径は $r=5.262 \mathrm{~m}$ で 1 掘削長は $l_{r}=1.0 \mathrm{~m}$ である. 傾斜 計測結果から推定した天端沈下収束值の分布は天端沈下 計測值の分布と概ね形状が一致する．ただし，TD221 m, TD226m，TD251 m，TD291 m，およびTD316mでは，そ の他の計測断面と比較して乘離差が大きく, 過小な推定 結果となっている. これらの断面では, 椿坂トンネルと 同様に切羽がトンネル掘削幅 $\left(D_{0} \fallingdotseq 11 \mathrm{~m}\right)$ 以上離れた

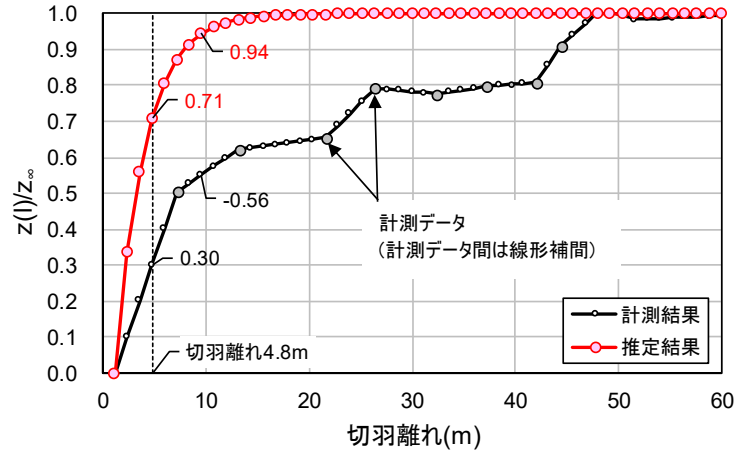

図-13 沈下特性曲線の相違

段階でも顕著な沈下の増加傾向が確認されており，実際 の地山挙動が推定式を導出したような弾性地山の挙動と は異なる挙動を呈していた.

椿坂および箕面トンネルの考察結果より，提案する天 端沈下量の推定方法の適用範囲は, 切羽直近部において 天端沈下の大部分が発生するような弾性的な地山挙動を 呈する場合である.このため, 地山条件（強度特性や粘 弾性特性）や施工条件（掘削工法や支保条件）に起因し て, 切羽直近部に対して切羽離れが大きくなった際に, 沈下が顕著に増加する場合には，それらを考慮した変位 特性曲線とフィッティング関数を使った天端沈下量の推 定方法を都度検討寸る必要がある。このためには，トン ネル全線で日常的かつ継続的に実施して, サイト特有の 変位挙動と傾斜角度の関係を把握する事が肝要である.

\section{（2）切羽前方地山の天端沈下量推定方法 \\ a) 天端沈下量推定方法（切羽前方地山）}

切羽前方地山で想定される天端沈下量は，実測におけ る傾斜角度標準值からの変動量を，4章で実施した感度 解析における各土被りと地山条件の組み合わせ毎の傾斜 


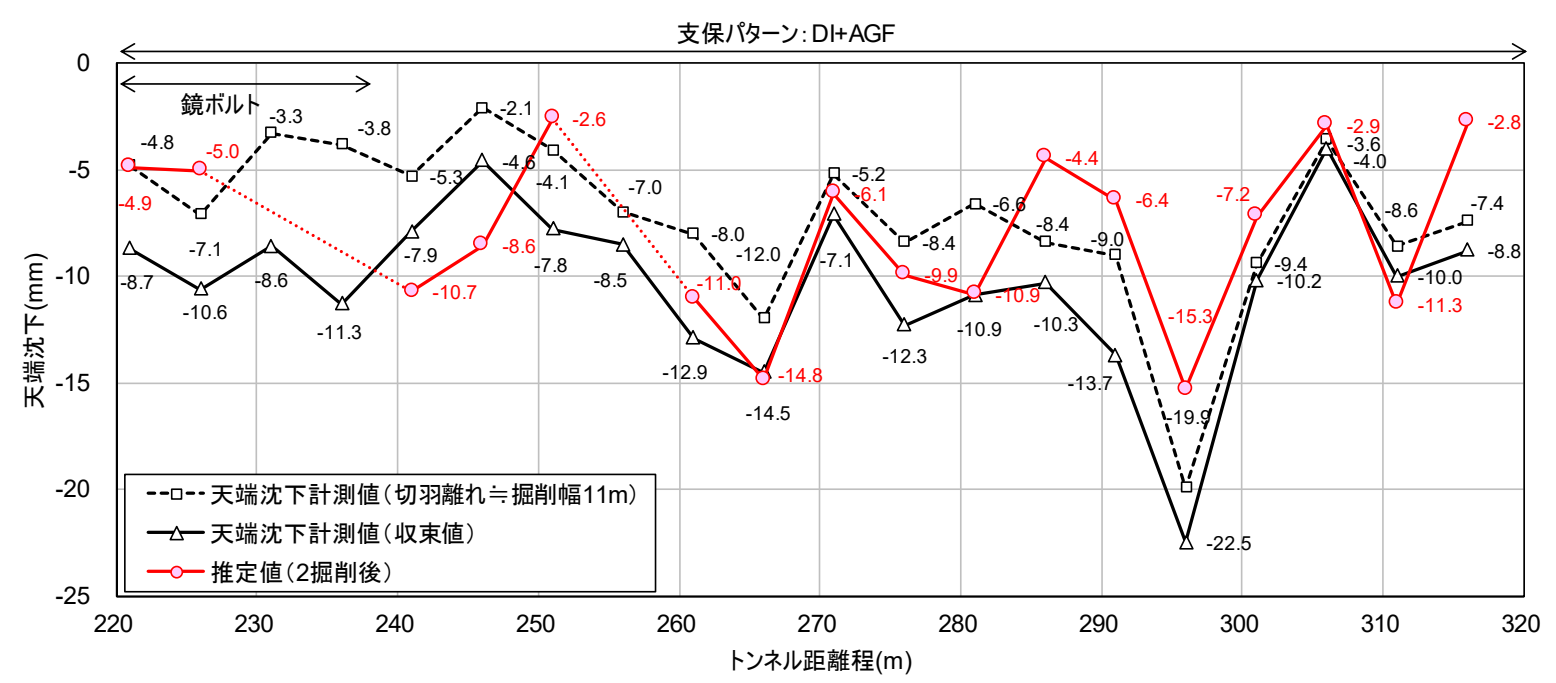

図-14 箕面トンネルにおける天端沈下量推定方法の事後評価結果

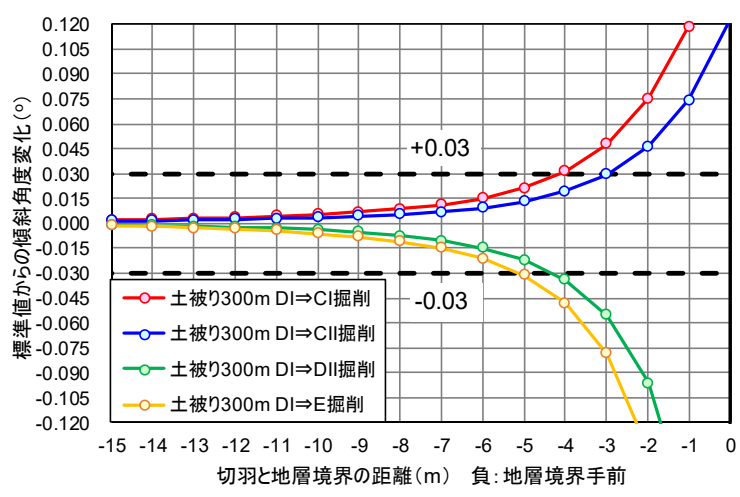

図-15 土被り $300 \mathrm{~m}$, DI 地山掘削時の傾斜角度変化

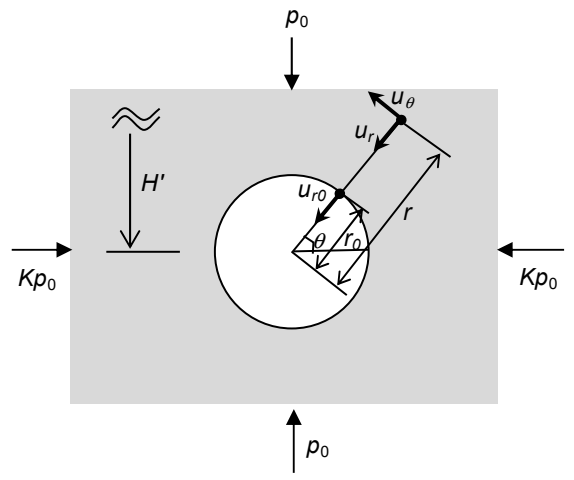

図-16 トンネル壁面変位の円孔理論解
角度標準值からの変動量と比較することで，地層境界位 置と地山等級を推定し, 解析結果の天端沈下量を予測值 として採用するものとした. 解析条件以外の土被りや掘 削径でも予測方法を適用できるようにするため, 理論解 と経験式を用いて感度解析の結果を補正する方法も併せ て検討した，以下に，図-6の感度解析結果を例として具 体的な推定方法を説明する.

例えば，土被り $300 \mathrm{~m}$ で掘削半径 $r=5 \mathrm{~m}$ のトンネル施 工時に傾斜計測を実施し，標準值から-0.03 （切羽側 増加）だけの変化が確認された場合を想定する. 図-15 に感度解析結果における地層境界手前（領域 I）での, 領域 II の地山条件毎の傾斜角度標準值からの変動量分布 を示す． $-0.03^{\circ}$ の傾斜角度変化は，図-15 の変動量を参照 すると，E地山との地層境界の $5 \mathrm{~m}$ 手前，もしくはDII地 山との地層境界の $4 \mathrm{~m}$ 手前である可能性があると考えら れる.このため, $4 \mathrm{~m}$ 前方では DII 地山相当の天端沈下 量（数值解析では-175 mm）が， $5 \mathrm{~m}$ 前方では E地山相当 の天端沈下量（数值解析では-328 mm）が発生する可能 性があると予測することができる，逆に+0.03の変化が 確認された場合には，同図より $3 \mathrm{~m}$ 前方では CII 地山
(数值解析では天端沈下量-25 mm) まで, $4 \mathrm{~m}$ 前方であ れば CI 地山（数值解析では天端沈下量- $12 \mathrm{~mm}$ ）に地山 等級が改善する可能性があると予測することができる. ただし，感度解析結果は特定の土被りと掘削半径を想定 したものであるため, 任意条件での解析結果の活用を目 的として，次に解析結果の補正方法を検討した.

\section{b) 傾斜角度解析結果の一般化}

掘削対象となる地山の応力一ひずみ関係を線形弾性と して，初期地圧条件として側圧係数 $K$ を仮定する. トン ネルは掘削半径 $r 0$ の円形トンネルであるとする．この時， 図-16 に示すトンネル中心から半径方向に $r$ の位置にお けるトンネル掘削に伴う半径方向の地山変位量 $u_{r}$ は Kirsch の円孔理論解として式(8)で与えられる例えば48),49).

$$
\begin{aligned}
u_{r}= & \frac{p_{0} r_{0}^{2}}{4 G r}[(1+K) \\
& \left.-(1-K)\left\{4(1-v)-\frac{r_{0}^{2}}{r^{2}}\right\} \cos 2 \theta\right]
\end{aligned}
$$

ここで, $p_{0}\left(\mathrm{kN} / \mathrm{m}^{2}\right)$ は鉛直方向応力であり，均質地盤の 場合にはトンネル中心深度に比例し $p_{0}=\gamma H^{\prime}$ と表すこ 
とができる， $\gamma\left(\mathrm{kN} / \mathrm{m}^{3}\right)$ は地山の単位体積重量, $H(\mathrm{~m})$ は卜 ンネル中心深度, $G\left(\mathrm{kN} / \mathrm{m}^{2}\right)$ は地山のせん断岡性率， 忙 地山のポアソン比, $\theta(\mathrm{rad})$ は図-16 における水平応力軸か らの回転角度である.

式(8)は側圧係数 $K=1.0$ の場合には，式(9)のように簡略 化することができ，さらにトンネル壁面位置 $r=r_{0}$ では 式(10)のように書くことができる.

$$
\begin{gathered}
u_{r}=p_{0} \cdot \frac{r_{0}}{2 G} \cdot \frac{r_{0}}{r}=\gamma H^{\prime} \cdot \frac{r_{0}}{2 G} \cdot \frac{r_{0}}{r} \\
u_{r_{0}}=\gamma H^{\prime} \cdot \frac{r_{0}}{2 G}
\end{gathered}
$$

式(10)は，トンネル壁面変位はトンネル中心深度と掘削 半径に比例することを意味する．ここで， $u_{r_{0}}$ は切羽到 達前の先行変位を含む全変位量である. 切羽通過後変位 $u_{r_{0}}^{\prime}$ は先行変位率を $x$ とした場合には, $u_{r_{0}}^{\prime}=(1-x) \cdot u_{r_{0}}$ と書くことができるため, 切羽通過後変位 $u_{r_{0}}^{\prime}$ も同様に トンネル中心深度と掘削半径に比例する. このため, 例 えば，掘削半径 $r_{0}=5 \mathrm{~m}$ と $r_{0}=6 \mathrm{~m}$ の切羽通過後のトンネ ル壁面変位である天端沈下量の収束値 $z_{\infty}$ は式(11)のよう に比例関係で表現できる.

$$
z_{\infty, r_{0}=6 \mathrm{~m}}=\frac{6}{5} \cdot z_{\infty, r_{0}=5 \mathrm{~m}}
$$

トンネル天端部の傾斜角度は, 式(4)に式(5)を代入し， 式(12)と式(13)のように表現することができる.

$$
\phi\left(2.5 l_{r}\right)=\frac{180}{\pi} \cdot \tan ^{-1}\left\{z_{\infty} \cdot f\left(r_{0}, 2.5 l_{r}\right)\right\}
$$

$$
\begin{aligned}
& f\left(r_{0}, 2.5 l_{r}\right) \\
& =\left[\begin{array}{c}
\left\{1-\exp \left(\frac{-2 l_{r}}{0.7 r_{0}}\right)\right\}-\left\{1-\exp \left(\frac{0}{0.7 r_{0}}\right)\right\}- \\
\left\{1-\exp \left(\frac{-3 l_{r}}{0.7 r_{0}}\right)\right\}+\left\{1-\exp \left(\frac{-1 l_{r}}{0.7 r_{0}}\right)\right\}
\end{array}\right] / l_{r}
\end{aligned}
$$

ここで, 式(13)で $f(n, 2.5 l)$ は掘削半径 $r$ と 1 掘削長 $l$ をを代 入する事により計算できる定数項である. また，天端沈 下量の収束值 $z_{0}$ は，掘削半径に比例する值として式(11) で例示したように, 解析条件以外の掘削半径の值でも解 析值を基に算出される.このため, 傾斜角度分布につい ても異なる掘削半径でも推定することが可能である. 例 えば, $r=6 \mathrm{~m}$ の傾斜角度標準值は $r=5 \mathrm{~m}$ の解析結果よ り，式(14)のように計算される.

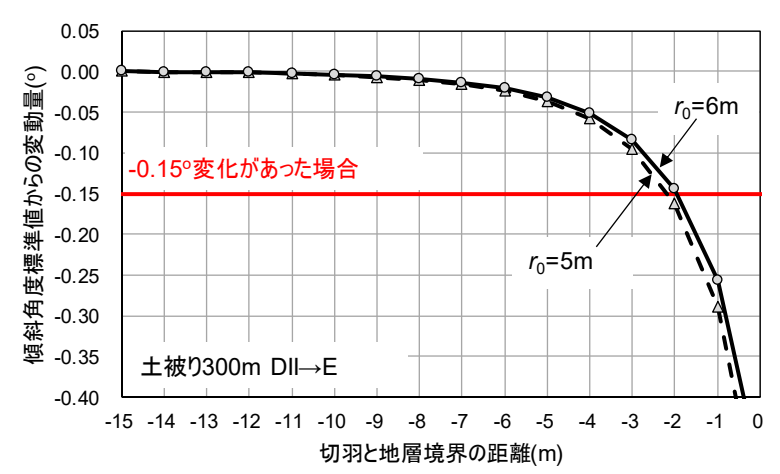

図-17 $r_{0}=5 \mathrm{~m}$ と $r_{0}=6 \mathrm{~m}$ の傾斜角度標準值からの変動量

$$
\begin{aligned}
& \phi\left(r_{0}=6 \mathrm{~m}, 2.5 l_{r}\right) \\
& =\frac{180}{\pi} \cdot \tan ^{-1}\left\{\frac{6}{5} \cdot z_{\infty, r_{0}=5 \mathrm{~m}} \cdot f\left(r_{0}=6 \mathrm{~m}, 2.5 l_{r}\right)\right\}
\end{aligned}
$$

式(14)は一様な地盤中の傾斜角度標準值であるが，掘 削半径 $n=6 \mathrm{~m}$ での異なる剛性を有する地山との地層境 界近傍の傾斜角度変化は, 解析結果との比を使うことで 推定できる. 以下に，土被り $300 \mathrm{~m}$ で DII 地山掘削時の $r 0=5 \mathrm{~m}$ の解析結果として得られた傾斜角度分布を同じ地 山条件で $r_{0}=6 \mathrm{~m}$ 一補正する. DII 地山では, 1 掘削長 $l_{r}=$ $1.0 \mathrm{~m}$ であることから $f\left(r=6 \mathrm{~m}, 2.5 l_{r}=2.5 \mathrm{~m}\right)$ は，式(14)に $r$ $=6 \mathrm{~m}, l_{r}=1 \mathrm{~m}$ を代入する事で, 式(15)のように計算され る. 同様に, $f\left(r 0=5 \mathrm{~m}, 2.5 l_{r}=2.5 \mathrm{~m}\right)$ は式 $(16)$ で表される.

$$
\begin{aligned}
& f\left(r_{0}=6 \mathrm{~m}, 2.5 l_{r}=2.5 \mathrm{~m}\right)=0.080 \\
& f\left(r_{0}=5 \mathrm{~m}, 2.5 l_{r}=2.5 \mathrm{~m}\right)=0.108
\end{aligned}
$$

解析結果より土被り $300 \mathrm{~m}$ で DII 地山中の天端沈下量の 収束值は $z_{\infty, r_{0}=5 \mathrm{~m}}=-221.6 \mathrm{~mm}$ である.このため掘削 半径 $n=5 \mathrm{~m}$ と $n=6 \mathrm{~m}$ の傾斜角度比は式(17)で表される.

$$
\begin{aligned}
\frac{\phi\left(r_{0}=6 \mathrm{~m}, 2.5 l_{r}=2.5 \mathrm{~m}\right)}{\phi\left(r_{0}=5 \mathrm{~m}, 2.5 l_{r}=2.5 \mathrm{~m}\right)} \\
=\frac{\tan ^{-1}\left\{6 / 5 \cdot z_{\infty, r_{0}=5 \mathrm{~m}} \cdot 0.080\right\}}{\tan ^{-1}\left\{z_{\infty, r_{0}=5 \mathrm{~m}} \cdot 0.108\right\}} \\
=0.890
\end{aligned}
$$

式(17)を用いる事により， $r=5 \mathrm{~m}$ の傾斜角度分布を，同 じ地山条件で $n=6 \mathrm{~m}$ 一補正することができ，地層境界 からの距離に応じた標準值からの変動量の分布も図-17 のように求められる. 図-17 は, DII 地山の前方に E地山 が存在するケースであるが，例えば， $-0.15^{\circ}$ の傾斜角度 の変動量が計測された場合には, 切羽前方約 $2 \mathrm{~m}$ で E地 山への剛性低下が予測されることを意味する. 


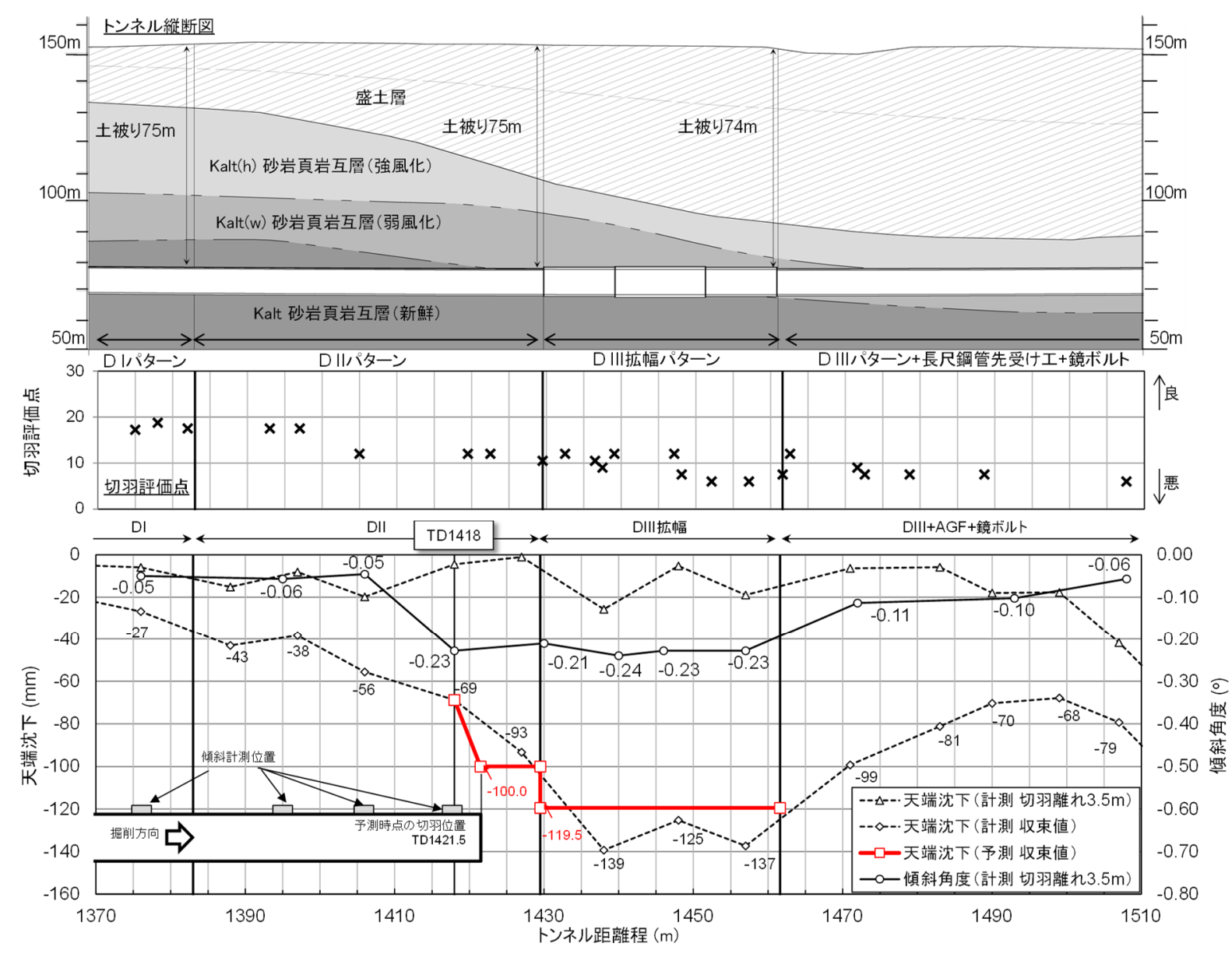

図-18 傾斜角度分布と天端沈下量の推定結果（葉山島トンネル)

\section{c) 推定方法の適用性検証}

現場実装試験で, 明確な傾斜角度標準值からの変動量 が確認された葉山島トンネルの結果 355396を使って, 前項 までに示した切羽前方地山における天端沈下量の推定方 法と，解析結果の一般化方法の妥当性について検証した 葉山島トンネルは，道路トンネルで計測区間は砂岩頁岩 が互層に分布する地山条件であり, 掘削工法はショート ベンチカット工法である。計測区間で採用した支保は起 点側より DI パターン（掘削断面積 $88.0 \mathrm{~m}^{2}$ ) , DII パター ン（掘削断面積 $91.6 \mathrm{~m}^{2}$ ) , DIII (拡幅) パターン（掘削 断面積 $125.8 \mathrm{~m}^{2}$ ），およびDIIIパターン（掘削断面積 99.2 $\mathrm{m}^{2}$ ) であった. 図-18に現場実装試験結果を示寸。

TD1429.5〜TD1462 m の DIII（拡幅）パターン区間での 切羽観察では，地山は暗黒色頁岩が大部分を占め，風化 と劣化した粘土分を多く含み岩塊は指圧で潰す事ができ る程度の硬さであり, 非常に脆弱な状態であった. 切羽 評価点（図-18 中段）は 10 点を下回る区間もあり，鏡面 の自然崩落は見られないものの, 機械掘削の打撃で容易 に掘削される状況であった。このような地山条件が掘削 により顕在化し，天端沈下量は最大 $139 \mathrm{~mm}$ を記録した。

傾斜角度は，初期值を切羽離れ $0.5 \mathrm{~m}$ で取得し（1 掘削 長は $1 \mathrm{~m})$, 切羽離れ $3.5 \mathrm{~m}$ まで顕著な増加傾向が確認で
きたため，同時点において評価した．DII 区間の地山を 掘削中において，脆弱な DIII（拡幅）パターンに到達す る直前の TD $1418 \mathrm{~m}$ で傾斜角度は, それまでの- $0.05^{\circ}$ から $-0.23^{\circ}$ まで $0.18^{\circ}$ だけ明確に切羽側一増加し，切羽前方に 軟弱層が存在することを定性的に予測することができた. このため, 傾斜角度標準值を- $0.05^{\circ}$, 傾斜角度標準值か らの変動量を- $0.18^{\circ}$ として, 切羽前方での天端沈下量を 推定した。 なお，4章で実施した感度解析で，DIIよりも 変形係数の劣る地山は, $\mathrm{E}$ 地山の夕を検討したため, 葉 山島トンネルで DII 区間の前方に存在する軟弱層の地山 条件は数值解析の E 地山に相当するものとし， DIII およ びDIII（拡幅）区間と同等と仮定した.

図-18では，比較のために傾斜角度を評価した切羽離 れ $3.5 \mathrm{~m}$ 時点における天端沈下量の距離程分布も描画し た. 同時点でトータルステーションによる手動計測が実 施されなかった計測断面では, 切羽離れ $3.5 \mathrm{~m}$ 前後の計 測值を線形補間することにより, 切羽離れ $3.5 \mathrm{~m}$ 時点の 天端沈下量を算出した. 切羽離机 $3.5 \mathrm{~m}$ 時点の天端沈下 量分布では，DIII（拡幅）区間に至る手前の TD1418mや $\mathrm{TD} 1427 \mathrm{~m}$ であっても変位の有意な増加傾向は認められ ない. このため, 天端沈下量の計測だけでは地山変化を 予測することは難しいと考えられ，傾斜計測による切羽 


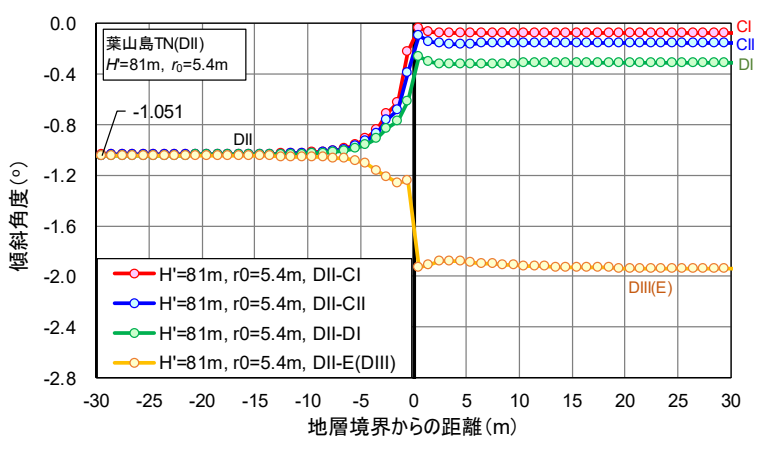

図-19 傾斜角度分布 $\left(H^{\prime}=81 \mathrm{~m}, r=5.400 \mathrm{~m}, \mathrm{DII}\right.$ 地山 $)$

前方地山予測の有効性を確認することができた.

計測区間の土被りは概ね $75 \mathrm{~m}$ （トンネル中心深度は $H$ $=81 \mathrm{~m})$ であり, TD1418 m での地山等級は DII で, 採用 された支保パターンの掘削断面積 $\left(91.6 \mathrm{~m}^{2}\right)$ と等価な断 面積を持つ円形トンネルの掘削半径は $r=5.400 \mathrm{~m}$ であっ た. そこで，解析結果の土被り $100 \mathrm{~m}$ （トンネル中心深 度 $H=105 \mathrm{~m}$ ）でDII 地山掘削時の傾斜角度分布を補正し て，上述の葉山島トンネルで DII 地山の前方に DIII（E) 地山が存在する場合の傾斜角度分布と標準值から変動量 を算出した. 掘削半径と 1 掘削長から求められる式(13) の定数項は, 掘削半径 $r=5.000 \mathrm{~m}$ と掘削半径 $r=5.400 \mathrm{~m}$ の時，それぞれ式(18)と式(19)で表される.

$$
\begin{aligned}
& f\left(r_{0}=5.000 \mathrm{~m}, 3.5 l_{r}=3.5 \mathrm{~m}\right)=0.143 \\
& f\left(r_{0}=5.400 \mathrm{~m}, 3.5 l_{r}=3.5 \mathrm{~m}\right)=0.127
\end{aligned}
$$

これらの定数項と, 解析結果で得た土被り $100 \mathrm{~m}, \mathrm{DII}$ 地 山掘削時の切习习通過後の天端沈下量- $73.3 \mathrm{~mm}$ を使うこと で, 葉山島トンネルの施工条件を反映した傾斜角度と数 值解析の傾斜角度の比率は，式(20)のように計算される。

$$
\begin{aligned}
& \frac{\phi\left(r_{0}=5.4 \mathrm{~m}, 3.5 l_{r}=3.5 \mathrm{~m}, H^{\prime}=81 \mathrm{~m}\right)}{\phi\left(r_{0}=5.0 \mathrm{~m}, 3.5 l_{r}=3.5 \mathrm{~m}, H^{\prime}=105 \mathrm{~m}\right)} \\
& =\frac{\tan ^{-1}\left\{\frac{5.4}{5.0} \cdot \frac{81}{105} \cdot z_{\infty, r_{0}=5 \mathrm{~m}, H^{\prime}=105 \mathrm{~m}} \cdot 0.127\right\}}{\tan ^{-1}\left\{z_{\infty, r_{0}=5 \mathrm{~m}, H^{\prime}=105 \mathrm{~m}} \cdot 0.143\right\}} \\
& =0.742
\end{aligned}
$$

図-19 は，土被り $100 \mathrm{~m} （$ トンネル中心深度 $H=105 \mathrm{~m}$ ）， DII 地山掘削時の解析結果に式(20)で得られた傾斜角度の 補正比率を乗じることにより算出した, 葉山島トンネル の施工条件における傾斜角度分布である. 図-20 は傾斜 角度標準值（図-19 より，-1.051） からの変動量である。

ここで，葉山島トンネルの DII 区間で計測した傾斜角 度標準值 $\left(-0.05^{\circ}\right)$ は数值解析で得られた傾斜角度標準 值 $\left(-1.051^{\circ}\right)$ に比べて小さい特徵がある.この原因の一

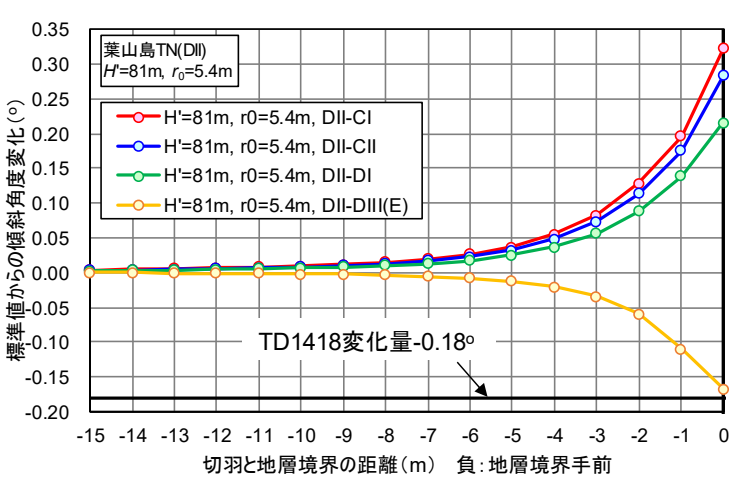

図-20 傾斜角度变動量 $(H=81 \mathrm{~m}, r=5.400 \mathrm{~m}, \mathrm{DII}$ 地山 $)$

つとして，数值解析では全断面掘削であるのに対し，実 施工では, ショートベンチカット工法であることが挙げ られる. 実施工では, 切羽離れ $3.5 \mathrm{~m}$ の時点では, 上半 部しか切羽が通過しておらず，下半掘削分の傾斜角度増 分がほとんど計測值に反映されていない，このため，傾 斜角度絶対值が小さくなったと推察される. また, 数值 解析では考慮していない支保の変位抑制効果によって, 天端沈下と共に，傾斜角度の絶対值も抑制されたことも， もう一つの要因として考えられる.

数值解析に比べ, 発生寸る傾斜角度が抑制されている と考えられる中でも，図-20にTD1418m で計測された変 動量- $0.18^{\circ}$ を重致ると, 数值解析の全断面掘削で, DII 地 山前方に DIII（E）相当の地山が存在する場合で，切羽 が既に地層境界に到達している状況に近い.このため, 切羽直近で DIII（E）地山に軟弱化するものと想定した. そこで, DIII（E）地山相当の天端沈下量を計算した. 式(10)から，等方応力場の弾性地山中での円形トンネル 掘削では, 壁面変位は掘削半径とトンネル中心深度に比 例する．そこで，土被り $100 \mathrm{~m}$, DIII（E）地山の切羽到 達後の天端沈下量 $(-137 \mathrm{~mm})$ を使って, 式(21)のように 葉山島トンネルの土被りと掘削断面積での切羽通過後の 天端沈下量を計算し，式(22)で計測変位相当值とした.

$$
\begin{aligned}
& \begin{aligned}
z_{\infty, r_{0}=5.4 \mathrm{~m}, H=75 \mathrm{~m}} & =\frac{5.4}{5.0} \cdot \frac{81}{105} \cdot(-137.0) \\
& =-114.1(\mathrm{~mm})
\end{aligned} \\
& z_{\infty, r_{0}=5.4 \mathrm{~m}, H=75 \mathrm{~m}}-z(0.5 \mathrm{~m}) \\
& =-114.1-\left\{-114.1 \cdot\left(1-\exp \left(\frac{-0.5}{0.7 \cdot 5.4}\right)\right)\right\} \\
& =-100.0(\mathrm{~mm})
\end{aligned}
$$

また，TD1429.5以降の拡幅区間でも同等の地山条件が 続くと考え，掘削半径を $5.400 \mathrm{~m}$ から拡幅区間の掘削断 面積 $\left(125.8 \mathrm{~m}^{2}\right)$ 相当の掘削半径 $r_{0}=6.328 \mathrm{~m}$ に変更して, 図-18に反映した.

天端沈下量の推定結果では，切羽直近部で-100.0 mm 
の沈下が発生すると予測された，一方，切羽前方で傾斜 計測断面に最も近い沈下計測点（TD1427 m）では，-93 $\mathrm{mm}$ の天端沈下収束値であったため, 推定結果は妥当で あったと考えられる．また，DIII（拡幅）区間では，推 定結果の-119.5 mm に対し計測結果は-125 - $139 \mathrm{~mm}$ であ り，推定結果として許容しうる誤差であった. このこと から, 同様の地山条件が続いて, 拡幅の影響で沈下が増 加したものと考えられる. この事後評価結果から, 提案 手法は妥当な天端沈下量の推定結果を与え，予防保全的 な補助工法等の検討に資することができる可能性がある。

ただし, 提案した天端沈下量の推定手法では, 数值解 析結果を援用寸る際に，地山条件，トンネル構造，およ び支保・掘削工法に仮定条件，すなわち弾性地山，円形 トンネル，無支保，および全断面掘削という条件を設け ている.このため, 推定結果の妥当性は適用するトンネ ルの施工条件や地山条件を踏まえて, 適宜検証と更新が なされる必要がある.そのためには，傾斜計測断面の天 端沈下量推定手法と同様に，特定の計測区間だけでなく， 計測区間を十分長くとって，天端沈下量と傾斜角度の相 関性を把握することが重要である.

\section{6. 結論}

本研究では，トンネル天端部で掘進方向の傾斜角度を 計測することによる切羽前方地山予測手法について，そ の適用可能範囲を明確化することを目的とした三次元逐 次掘削解析を実施した。 また，切羽前方での地山の岡性 変化に対して, 変化点の位置と変形量を予測する定量的 な方法へ傾斜角度計測手法を展開することを試みた．具 体的には, 傾斜角度の計測結果から計測断面と切羽前方 において発生する天端沈下量を定量的に推定する方法を 提案した. さらに, 推定手法の妥当性を検証するために, 現場実装試験の事後評価を行った.

本研究で得られた成果は, 以下のように整理される.

1) 線形弾性挙動を仮定した地山中で, 掘削半径 $r=5 \mathrm{~m}$ の円形トンネルを全断面掘削する条件の下で，土被 りと地山の変形係数の組み合わせをパラメータとし た感度解析を実施した。解析結果の傾斜角度分布か ら，切羽が地層境界一到達する前に，天端傾斜計の 計測精度である $0.01^{\circ}$ 以上の傾斜角度変化を生じる事 を傾斜計測手法の成立条件として，適用可能な地山 条件と土被りを検討した。この結果，傾斜計測手法 は, CI 地山の場合には土被り $400 \mathrm{~m}$ 以上, CII 地山の 場合には土被り $150 \mathrm{~m}$ 以上, DI より剛性の劣る地山 では，土被り $50 \mathrm{~m}$ 以上で適用できることを示した.

2) 感度解析結果から地山変化を見逃さないための傾斜 計測断面間隔を検討するノモグラムを提示した.
3) 傾斜計測断面での天端沈下量推定式では, 計測断面 前後の天端沈下量による傾斜角度算出式に, 切羽離 れに応じた壁面変位の進展を示寸変位特性曲線のフ イッティング関数を使って, 切羽通過直後の傾斜角 度と天端沈下量収束值との関連性を導出した。

4) 2 つの現場実装試験の事後評価を実施し, 傾斜計測 断面での天端沈下量推定手法の妥当性を検証した. 推定結果は計測結果と良く整合したと考えられるが, 推定手法では地山が弾性体として挙動し, 切羽直近 部で大部分の沈下が生じることを仮定している.す なわち, 切羽直近部での天端挙動がわずかで, 傾斜 角度も小さく計測される場合には，予測される天端 沈下量も当然小さくなる特徵がある. このため, ト ンネル周辺に生じた緩み域の影響や地山の粘弾性的 な挙動, もしくは施工方法に起因して切羽通過直後 よりも遠く離れた際に沈下が大きくなるような変形 モードの場合には，過小に沈下量を評価してしまう 可能性が示唆された.

5) 切羽前方地山の天端沈下量推定方法では, 計測され た傾斜角度標準值からの変動量と, 感度解析結果を 比較することで, 切羽前方に存在する可能性のある 地山条件とその出現位置を推定し, 解析結果により 得られた值を天端沈下量の推定值とした. この時, 掘削半径やトンネル中心深度が感度解析条件と異な る場合には, 感度解析により得られた傾斜角度分布 を, トンネル壁面変位量を計算する理論解を用いて 補正する方法を提案した.

6) 葉山島トンネルの現場実装試験で事後評価を実施し, 切羽前方地山での天端沈下量推定手法の妥当性を検 証した。計測区間では傾斜角度の標準值と，脆弱な 地山区間の手前で明確な傾斜角度変化が得られてい た. 切羽前方での天端沈下量の推定値は実測值と許 容しうる誤差程度であったため, 提案する推定手法 は有効であると考察した.

最後に今後の課題について言及する. 本研究で示した 傾斜計測手法の適用可能範囲，および天端沈下量の推定 方法は, どちらも弾性的な地山挙動を仮定した. 天端沈 下量の推定方法に関しては, 現場実装試験の事後評価を 実施して，ある一定の適用性があることを論じた。 しか し，上記 4)で論じたように切羽直近部で得られた傾斜角 度だけでは天端沈下量の推定值は過小評価につながるケ 一スもあることが課題である。したがって，現時点では 複数の手法を併用し, 推定值の信頼性向上や地質情報の 精度向上を図ることが必要とされる場合もある。例えば, ある計測断面において，切羽離れと伴に複数回計測され た天端沈下量の進展傾向から, その後に推定値を上回る 䀣念がある場合には，それまでに同断面で得た天端沈下 量の計測值を使った推定值の更新作業を行うことができ 
る. 一方，切羽前方地山での天端沈下量推定手法におい

て, 傾斜角度標準值から変動量が，現在の地山等級と比 較して大きな変化を示すものである場合には，探りボー リングや弾性波探査等の切羽前方探査を実施して地山状 況の情報精度を高める方法も考えられる.

さらに，未掘削区間へのフィードバックを目的に，本 研究で使った傾斜角度による天端沈下量の推定方法の弾 性地山挙動を仮定した変位特性曲線のフィッティング式 を，適用するトンネルの施工方法と地山条件に適したも のに適宜変更する必要もある。このためには，特定の計 測区間だけでなく，計測延長を十分に確保した傾斜計測 を日常の計測管理の一環で連続的に実施し，天端沈下量 との相関性を施工初期段階から把握し，関連性の更新作 業を継続的に行う必要がある. 今後，傾斜計測データの 蓄積によって，地山変化の予測手法と天端沈下量の推定 手法の両方について信頼性向上を図りたいと考えている.

\section{参考文献}

1) 山下雅之, 平野亨, 木村哲, 石井洋司 : 穿孔探査シ ステムによる支保パターン事前想定の試み, 土木学 会第 58 回年次学術講演会, III-155, pp.309-310, 2010.

2) 桑原徹, 畑浩二, 赤澤正彦：ノンコア削孔調査によ る山岳トンネル切羽前方探査精度の検討, トンネル 工学報告集, Vol.23, pp.1-9, 2013.

3) 白鷺卓, 宮嶋保幸, 山本拓治, 西川幸一, 福田博 之：トンネルの施工穿孔データを利用したオンタイ ム切羽評価と前方予測, トンネル工学報告集, Vol.27, I-19, 2017.

4) 村山秀幸, 岡崎健治, 山崎秀策, 倉橋稔幸, 亀村勝 美 : 切羽前方探査の調査手法と地山評価における現 状と課題に関する考察，トンネル工学報告集，Vol.29, I-9, 2019.

5) Teale, R.: The concept of specific energy in rock drilling, Int. Journal of Rock Mechanics and Mining Science, Vol.2, pp.57-73, 1965.

6) 西松裕一：掘削方法とその評価法について，日本鉱 業会合同秋季大会講演集, pp. 1-4, 1972.

7) 松井保 (監修), （一財）災害科学研究所トンネル 調査研究会（編）：トンネル技術者のための地盤調 査と地山評価, p.189, 2017.

8) Sattel, G., Frey, P. and Amberg, R.: Prediction ahead of the tunnel face by seismic methods - pilot project in Centovalli Tunnel, Locarno, Switzerland, First Break, Vol. 10, No. 1, pp. 19-25, 1992.

9) 岡部幸彦, 近藤達敏：トンネル掘削時におけるイン クリノメータによる地山変位挙動計測と切羽近傍の 地山物性值の推定, 応用地質年報, No.8, pp. 25-41, 1987.

10) 河内野俊治, 横尾利治, 福田耕二, 伊藤博司, 鶴原 敬久, 中西昭友: 孔内水平傾斜計を用いた都市トン ネルの計測管理, 第 33 回岩盤力学に関するシンポジ ウム講演論文集, pp. 259-264, 2004.

11）木野村有亮，磐田吾郎，木梨秀雄，辻村幸治：切羽 先行沈下システムの開発と適用, 土木学会第 69 回年 次学術講演会, VI-017, pp. 33-34, 2014.
12) Schneider-Muntau, B., Reinhold, C., Cordes, T., Bathaeian, I. and Bergmeister, K.: Validation of longitudinal displacement profiles by measurement at the Brenner Base Tunnel, Geomechanics and Tunnelling, Vol. 11, No. 5, pp. 566-574, 2018.

13）木梨英雄, 萩野知, 岡崎雄一, 鈴木拓也, 渡辺淳, 藤岡大輔：地山安定性評価のための二軸先行変位計 の開発，土木学会全国大会第 74 回年次学術講演会, III-276, 2019.

14）清水利郎, 尾畑洋, 松尾勉, 手塚仁, 岡部正 : 長尺 切羽補強工を施工した切羽前方地山の挙動について, トンネル工学研究論文・報告集, Vol. 13, pp. 225-230, 2003.

15) Steiner, R. P.: Displacement measurements ahead of a tunnel face using the RH Extensometer, Proc. of the 7th Int. Symposium on Field Measurements in Geomechanics, 2007.

16) 坂井一雄, 谷卓也, 文村賢一, 原靖浩, 後藤真之助, 原稔之: 都市部山岳トンネルにおける切羽先行変位 を用いた計測管理手法，第 44 回岩盤力学に関するシ ンポジウム講演集, pp. 92-97, 2016.

17) Sakai, K., Tani, T., Fumimura, K., Hara, Y., Goto, S. and Hara, T.: Case study of the displacement monitoring ahead of the face in an urban tunnel construction project, Proc. of the 2016 Korea-Japan Joint Symposium on Rock Engineering, pp. 111-115, 2016.

18）北野悠介, 文村賢一, 坂井一雄, 谷卓也, 原靖浩, 後藤真之助 : 福岡市地下鉄七隈線延伸事業における 都市 NATM の情報化施工（その 3 : 切羽先行変位計 測による周辺地山の挙動監視），土木学会第 71 回年 次学術講演会, VI-452, pp. 903-904, 2016.

19) 土木学会トンネル工学委員会 : トンネル標準示方書 [山岳工法] 同解説, pp.242-253, 2016.

20) Schubert, W. and Budil, A.: The importance of longitudinal deformation in tunnel excavation, Proc. of 8 th Int. Congress on Rock Mechanics (ISRM), Tokyo, Vol. 3, pp. 1411-1414, 1995.

21) Sellner, J. P. and Steindorfer, F. A.: Prediction of displacement in tunnelling, Felsbau, Vol. 18, No. 2, pp. 22-26, 2000.

22) Grossauer, K., Schubert, W. and Kim, C. Y.: Tunnelling in heterogeneous - stresses and displacements -, Proc. of 10th Int. Congress on Rock Mechanics (ISRM), Sandton, pp. 437-440, 2003.

23) Moritz, B., Goldberger, H. and Schubert, P.: Application of the observational method in heterogeneous rock mass with low overburden, Felsbau, Vol. 24, No. 1, pp. 62-72, 2006.

24) Austrian Society for Geomechanics: Geotechnical Monitoring in Conventional Tunnelling Handbook, pp. 57-63, 2014.

25) 小泉直人, 川原睦人, 黒田千歳: トンネル周辺地山 の違いによる切羽天端部の軸方向変位の挙動につい て, トンネル工学報告集, Vol. 19, pp. 211-217, 2009.

26) 寺島佳宏, 小川勲, 大沼正浩 : 三次元内空変位計測 結果の有効活用について, JCM マンスリーレポート, Vol. 19, No.13, pp.10-12, 2010.

27) 竹村いずみ, 進士正人, 鬼頭夏樹, 千々和辰訓, 石 山宏二：坑内の軸方向変位を用いた前方地山状況の 予測法の提案, トンネル工学報告集, Vol. 21, pp. 1-7, 2011.

28）竹村いずみ, 千々和辰訓, 石山宏二: 坑内計測デー 夕を用いた地山予測手法に関する研究 (PS-Tad), 西 
松建設技報，Vol. 37, No. 25, 2014.

29) Takemura, I., Shinji, M., Ishiyama, K. and Chijiwa, T.: The forward ground prediction chart by using axial displacement of the three dimensional convergence measurements, Proc. of 8th International Symposium on Field Measurements in GeoMechanics, Berlin, 2011.

30) 辻岡高志, 竹内秀頼, 竹村いずみ, 進士正人 : 天端 軸方向変位による前方地山予測法の改良を目指した 基礎的研究, トンネル工学報告集, Vol. 23, pp. 177182, 2013.

31) 青木智幸, 今中晶紹, 板垣賢, 領家邦泰, 金尾剣一, 櫻井春輔：トンネル坑内变位計測による切羽前方地 山予測, 第 39 回岩盤力学に関するシンポジウム, pp. 387-392, 2011.

32）工藤直矢, 坂井一雄, 青木智幸, 友野雄士, 三谷一 貴 : 坑内変位計測結果を用いた切羽前方地山予測, トンネル工学報告集, Vol. 21, pp. 127-133, 2011.

33) トプコン : SOKKIA CX Series 製品カタログ, 2012.

34) 坂井一雄, 岸田潔: 坑内変位計測結果を活用した切 羽前方地山予測手法の適用可能範囲, 第 15 回岩の力 学国内シンポジウム講演集, pp.183-188, 2021

35) 坂井一雄, 谷卓也, 青木智幸, 工藤直矢 : トンネル 天端の微小な傾斜角度の変化を用いた切羽前方地山 予測手法の開発，土木学会論文集 F1（トンネル工 学) , Vol. 73, No. 2, pp. 32-46, 2017.

36) Sakai, K., Tani, T., Aoki, T. and Ohtsu, H.: Inclination monitoring at tunnel crown to predict change in ground stiffness ahead of excavation face, Tunnelling and Underground Space Technology, Vol. 104, No.103516, 2020.

37) 工藤直矢, 坂井一雄, 青木智幸, 友野雄士, 三谷一 貴 : トンネル天端傾斜計測による切羽前方地山予測, 第 41 回岩盤力学シンポジウム講演集, pp. 23-28, 2012.

38) Jeon, S. J., Martin, D. C., Chan, H. D. and, Kim, S. J.: Predicting ground conditions ahead of tunnel face by vector orientation analysis, Tunnelling and Underground Space Technology, Vol. 20, pp. 344-355, 2005.

39) Lee, I. C., Park, J. Y. and Kim, Y. K.: Prediction of fault zones ahead of tunnel face using 3-D displacement monitoring, Proc. of the 5th Int. Asian Rock Mechanics, pp. 133146, 2008.

40）坂井一雄, 青木智幸, 清水賀之, 北澤翔平, 山中誠 一：坑内変位を用いた切羽前方地山予測に関する数 值解析, 土木学会第 65 回年次学術講演会, No.III-426, pp. 851-852, 2010.

41) Tani, T., Aoki, T., Kato, H. and Misumi, H.: Effectiveness of predicting ground conditions ahead of a tunnel face by measuring the inclination at the tunnel crown, Proc. of 8 th Asian Rock Mechanics Symposium, No. TUS4-5, 2014.

42) 日本道路公団試験研究所：トンネルの標準設計に関 寸る研究報告書一数值解析と施工実績の分析一, 1986.

43) 日本道路公団：トンネル数值解析マニュアル, pp.326, 1998.

44) 土木学会 トンネル工学委員会 技術小委員会 数值解 析・模型実験部会：トンネル・ライブラリー第 16 号, 山岳トンネルにおける模型実験と数值解析の実務, p. 152, 2006.

45) 土木学会トンネル工学委員会 : トンネル標準示方書 [山岳工法] 同解説, pp.76-79, 2016.

46) Sakai, K., Tani, T., Aoki, T. and Ohtsu, H.: Prediction of tunnel crown settlement by means of inclination monitoring, Proc. of ISRM 14th Int. Congress of Rock Mechanics, pp. 1277-1284, 2019.

47) Panet, M.: Time-dependent deformations in underground works, Proc. of the 4th Int. Congress of Rock Mechanics, Vol. III, pp. 279-289, 1979.

48）足立紀尚，矢野隆夫：トンネル掘削に伴う地山変位 計測結果の簡易解析，土木学会論文集，No. 388/III-8, pp. 207-216, 1987.

49) Brady, G. H. B. and Brown, T. E.: Rock Mechanics for Underground Mining, Third Edition, pp. 173-178, 2004.

(Received February 4, 2021)

(Accepted July 13, 2021)

\title{
APPLICABLE RANGE OF INCLINATION MONITORING METHOD FOR PREDICTION OF GEOTECHNICAL CONDITION AHEAD OF TUNNEL FACE AND ITS QUANTITATIVE EVALUATION
}

\author{
Kazuo SAKAI, Takuya TANI, Tomoyuki AOKI and Kiyoshi KISHIDA
}

Safe and cost-effective excavation of mountain tunnels requires accurate prediction of geotechnical condition ahead of the tunnel face and preventive auxiliary methods or appropriate support members should be adopted correspondingly. Authors have so far developed a method to predict the change in ground stiffness ahead of the tunnel face by means of inclination monitoring which can be applied without any hindrance to the construction. Applicability and validity of the method have been verified through numerical simulation and field measurement tests. This study performs parametric numerical simulations in which ground stiffness at the face under excavation and ahead of the face, and tunnel overburden are considered as variables in order to clarify the geotechnical condition required for the application of the proposed prediction method. The study also discusses a quantitative estimation method for the tunnel crown settlement by measured inclination. This leads to further effective use of ground prediction results in which allowable deformation volume and appropriate auxiliary methods required can be determined beforehand. Effectiveness of the estimation method is investigated through the post-evaluation of field measurement data. 